Jurnal IImiah AL-Jauhari (JIAJ)

Volume 2 No 1, Juni 2017

ISSN: $2541-3430$

E-ISSN: 2541-3449

Halaman 211-241

\title{
Pengaruh Pembelajaran Kitab Ta'lim Al-Muta'allim terhadap Pembentukan Karakter dan Prestasi Belajar Santri
}

Oleh: Ali Sabana Mudakir

\begin{abstract}
Abstrak
Kemerosotan akhlak santri terjadi karena santri tidak mengetahui adab dan tata cara menuntut ilmu yang baik dan benar. Kitab Ta'lim al-Muta'allim adalah kitab yang membahas tentang adab dan tata cara dalam menuntut ilmu. Dengan pembelajaran kitab Ta'lim al-Muta'allim diharapkan santri dapat memahami dan menguasai materi tersebut serta mempraktekkannya dalam kehidupan sehari-hari. Tujuan penelitian ini adalah untuk mengetahui besarnya pengaruh pembelajaran kitab Ta'lim al-Muta'allim terhadap pembentukan karakter dan prestasi belajar santri pesantren Hubulo.

Metode yang digunakan dalam penelitian ini adalah metode kuantitatif dengan pendekatan korelasi studi hubungan. Untuk mengetahui besarnya pengaruh pembelajaran kitab Ta'lim al-Muta'allim terhadap pembentukan karakter dan prestasi belajar, maka digunakan analisis regresi linier sederhana sebanyak dua kali dengan tingkat signifikan 5\%. Regresi pertama untuk mengetahui pengaruh pembelajaran kitab Ta'lim al-Muta'allim terhadap pembentukan karakter dan regresi kedua untuk mengetahui pengaruh pembelajaran kitab Ta'lim alMuta'allim terhadap prestasi belajar. Hasil penelitian menunjukkan adanya pengaruh positif dan signifikan dari hasil pembelajaran kitab Ta'lim alMuta'allim terhadap pembentukan karakter dan prestasi belajar santri pesantren Hubulo. Besarnya pengaruh pembelajaran kitab Ta'lim al-Muta'allim terhadap pembentukan karakter adalah 0,358 dan nilai konstan 37,154 dengan nilai signifikan 0,000, sedangkan besarnya pengaruh pembelajaran kitab Ta'lim alMuta'allim terhadap prestasi belajar adalah 0,390 dan nilai konstan 10,767 dengan nilai signifikan 0,000 . Perbedaan penelitian ini dengan penelitian sebelumnya adalah terletak pada variabel independennya (kitab Ta'lim al-Muta'allim ).
\end{abstract}

Kata Kunci: Kitab Ta'lim al-Muta'allim, Karakter, dan Prestasi Belajar, santri

\section{Pendahuluan}

Maraknya tindakan kekerasan, perpeloncoan, perkelahian, dan perilaku menyimpang dikalangan santri disebabkan oleh kemerosotan akhlak. Kemerosotan akhlak terjadi karena mereka tidak mengetahui bagaimana seharusnya menjadi santri yang baik. Oleh karena itu, pendidikan karakter diharapkan mampu menjawab persoalan tersebut. 
Karakter adalah tabiat, watak, sifat-sifat kejiwaan, akhlak dan budi pekerti yang membedakan seseorang dengan orang lain. ${ }^{1}$ Membentuk karakter santri tidaklah mudah, karena membutuhkan peran aktif dan dukungan dari berbagai pihak. Pihak-pihak yang berperan penting dalam pembentukan karakter santri adalah keluarga, sekolah dan lingkungan masyarakat.

Pembentukan karakter santri dimulai dari lingkungan keluarga. ${ }^{2}$ Keluarga merupakan pendidikan karakter santri yang pertama. Pemeran utama dalam pendidikan karakter di lingkungan keluarga adalah orang tua. Orang tua merupakan pijakan utama anak dalam berperilaku. ${ }^{3}$

Tahapan pendidikan karakter berikutnya adalah lingkungan sekolah. ${ }^{4}$ Sekolah memiliki andil besar dalam membentuk karakter santri. Pada tahapan ini santri sudah mulai berinteraksi dengan situasi sosial yang lebih luas. Santri dituntut untuk berinteraksi dengan santri lainnya. Santri mulai memperoleh pengalaman baru, berupa teman baru yang memiliki latar belakang pendidikan keluarga yang berbeda-beda. Secara langsung maupun tidak langsung teman di sekolah akan mempengaruhi karakter santri. Pendidikan karakter santri di sekolah dominan dipengaruhi oleh guru. ${ }^{5}$ Pembentukan karakter yang dilakukan guru adalah melalui proses pembelajaran dan keteladanan.

Pendidikan karakter santri yang terakhir adalah lingkungan masyarakat. ${ }^{6}$ Lingkungan masyarakat memiliki peranan yang sangat besar dalam membentuk karakter santri. ${ }^{7}$ Setelah santri mendapatkan pendidikan di lingkungan keluarga dan sekolah, maka santri akan berbaur dengan lingkungan masyarakat. Secara langsung santri akan diperhadapkan pada situasi sosial yang lebih luas dan heterogen. Santri mulai bergaul dengan siapapun tanpa batas. Mulai dari anakanak, teman sejawat dan bahkan orang yang lebih tua. santri akan mendapatkan pengalaman baru dengan melihat secara langsung gejala-gejala yang terjadi di masyarakat, apabila lingkungan masyarakat baik, maka santri akan cenderung berperilaku baik dan sebaliknya.

Pendidikan karakter bertujuan membentuk santri menjadi pribadi yang baik secara lahir dan batin. Menurut Mochtar Buchori, pendidikan karakter seharusnya membawa peserta didik kepada pengenalan nilai secara kognitif, penghayatan nilai afektif, dan akhirnya ke pengamalan nilai secara nyata. ${ }^{8}$

${ }^{1}$ Abdul Majid \& Dian Andayani, Pendidikan Karakter Perspektif Islam, (Bandung: PT. Remaja Rosdakarya, 2011), h. 11.

${ }^{2}$ Syamsul Kurniawan, Pendidikan Karakter : Konsepsi \& Implementasinya Secara Terpadu Di Lingkungan Keluarga, Sekolah, Perguruan Tinggi, \& Masyarakat, (Yogyakarta: ArRuzz, 2013), h. 43.

${ }^{3}$ Sudarsono, Etika Islam Tentang Kenakalan Remaja, (Jakarta: Bina Aksara, 1989), h. 19.

4 Moh. Haitami Salim dan Syamsul Kurniawan, Studi Ilmu Pendidikan Islam, (Yogyakarta: Ar-Ruzz Media, 2012), h. 268.

5 Ahmad D. Marimba, Pengantar Filsafat Pendidikan Islam, (Bandung: Remaja Rosdakarya, 1989), h.37.

${ }^{6}$ Syamsul Kurniawan, Pendidikan Karakter, h, 49.

${ }^{7}$ Moh. Haitami Salim dan Syamsul Kurniawan, Studi Ilmu Pendidikan, h. 271.

${ }^{8}$ Syamsul Kurniawan, Pendidikan Karakter, h, 31-32. 
Santri dikatakan berkarakter baik apabila di dalam dirinya tertanam nilai-nilai religius, tanggung jawab, disiplin, mandiri, jujur, hormat, santun, kasih sayang, peduli, kerjasama, percaya diri, kreatif, kerja keras, pantang menyerah, adil, kepemimpinan, baik, rendah hati, toleransi, cinta damai dan persatuan. ${ }^{9}$ Oleh karena itu, pendidikan karakter adalah suatu keniscayaan.

Prestasi belajar adalah hasil perubahan ranah psikologis sebagai akibat pengalaman dan proses belajar santri yang tercapai dalam kurun waktu tertentu. ${ }^{10}$ Prestasi belajar merupakan bagian penting dalam dunia pendidikan. Prestasi belajar memiliki tiga ranah yang harus dicapai dengan baik oleh setiap santri. Tiga ranah tersebut adalah ranah kognitif, ranah afektif dan ranah psikomotorik. ${ }^{11}$

Berprestasi merupakan tujuan setiap santri. Santri yang berprestasi cenderung lebih percaya diri dibandingkan dengan santri yang tidak berprestasi. Untuk mencapai tujuan tersebut, maka santri harus melakukan usaha-usaha maksimal untuk meraihnya. Usaha-usaha tersebut akan tercapai apabila santri mengetahui cara belajar yang baik dan benar.

Pesantren merupakan lembaga pendidikan yang berciri khas pendidikan Islam. Pembentukan karakter dan prestasi belajar santri adalah tujuan utama pendidikan pesantren. Karakter dan prestasi belajar santri dibentuk sesuai dengan ajaran Islam. Salah satu usaha yang dilakukan dalam membentuk karakter dan prestasi belajar santri adalah melalui pembelajaran kitab Ta' lim al-Muta'allim.$^{12}$

Kitab Ta'lim al-Muta'allim merupakan ilmu pondasi dasar dalam membentuk karakter dan prestasi belajar santri. Kitab ini diyakini oleh masyarakat pesantren mampu membentuk karakter dan prestasi belajar santri, sehingga kitab ini dijadikan mata pelajaran wajib pesantren. Santri yang telah mempelajari kitab Ta'lim al-Muta'allim dan mengamalkannya, maka santri tersebut dianggap telah siap untuk menerima dan mempelajari ilmu-ilmu pengetahuan yang lain.

\section{A. Pembelajaran Kitab Ta'lim al-Muta'allim}

Pembelajaran adalah upaya untuk membelajarkan siswa. ${ }^{13}$ Kitab Ta'lim al-Muta'allim adalah kitab yang membahas tentang adab dan tata cara santri dalam menuntut ilmu. ${ }^{14}$ Pembelajaran kitab Ta'lim al-Muta'allim adalah upaya yang dilakukan untuk membelajarkan adab dan tata cara dalam menuntut ilmu kepada santri.

Nama lengkap kitab Ta'lim al-Muta'allim adalah Ta'lim alMuta'allim u fi Thariqi at-Ta'allum. Kitab Ta'lim al-Muta'allim yang dikarang oleh syekh Az-Zarnuji yang memiliki nama lengkap Tajuddin Nu'man bin

9 Abdullah Majid, Dian Andayani, Pendidikan Karakter Perspektif Islam, cet. II (Bandung: PT. Rosda Karya, 2012), h. 42; Lihat visi misi Pesantren Hubulo.

${ }^{10}$ Muhibbin Syah, Psikologi Pendidikan Dengan Pendekatan Baru, (Bandung: Rosda, 2014), h. 148.

${ }^{11}$ Muhibbin Syah, Psikologi Pendidikan, (Bandung: PT. Remaja Rosda Karya, 1995), h.141.

${ }^{12}$ Kitab Ta'limu al-Muta'allim adalah karangan Syeikh Burhanudin Az-Zarnuji tentang adab dan tata cara dalam menunt ut ilmu.

${ }^{13}$ Hamzah B. Uno, Perencanaan Pembelajaran, (Jakarta: Bumi Aksara, 2008), h. 2.

${ }^{14}$ Abdul Kadir al-Jufri, Terjemah Ta'lim Muta'allim, (Surabaya: Mutiara Ilmu Surabaya, 1995), h. 1 . 
Ibrahim bin al-Khalil Zarnuji. ${ }^{15}$ Syekh Az-Zarnuji adalah seorang sastrawan dari Bukhara, yang dikenal dengan karyanya kitab Ta'lim al-Muta'allim . ${ }^{16}$

Beliau hidup pada abad ke VI Hijriyah atau sekitar abad 13-14 M. Imam Al-Ghazali menjelaskan bahwa syekh Az-Zarnuji menimba ilmu pengetahuan dari berbagai ulama pada masanya. Syekh Az-Zarnuji telah banyak mengarang kitab-kitab fiqih, bahasa dan sastra yang beraliran Madzhab Hanafi. ${ }^{17}$

Guru-guru syekh Az-Zarnuji yang terkenal adalah imam Abu Hanifah, syekh Al-Murghinani, syekh Muhammad bin Hasan, syekh Abu Yusuf, syekh Hammad bin Ibrahim, syekh imam Sadidudin Asy-Syairazy, syekh Hilal bin Yasar, syekh Qiwamuddin, syekh Al-Hamdani, syekh Al-Hulwani, syekh AshShadru Asy-Syahid, syekh Ali bin Abi Bakr bin Abdul Jalil al-Farghani alRustami Ruknul Islam Muhammad bin Abi Bakar, dan syekh Taqruddin al-Hasan bin Mansur. ${ }^{18}$

Syekh Az-Zarnuji menuntut ilmu di Bukhara dan Samarkand yang menjadi kota pusat keilmuan. Di dua kota tersebut beliau belajar kepada syekh Burhanudin Al-Murghinani, syekh Syamsudin Abd. al-Wajdi, dan syekh Muhammad bin Muhammad al-Abd As-Sattar Al-Amidi. ${ }^{19}$ Wafatnya syekh AzZarnuji memiliki keterangan yang berbeda-beda. Ada yang menyebutkan tahun $591 \mathrm{H}, 593 \mathrm{H}$, dan $597 \mathrm{H}^{20}$

Kitab ini dikarang berdasarkan keresahan beliau yang melihat keadaan orang-orang yang bersungguh-sungguh dalam menuntut ilmu, akan tetapi tidak mendapatkan manfaat dari ilmu yang dipelajari berupa pengamalan ilmu tersebut dalam menyebarkannnya. ${ }^{21}$ Hal ini terjadi karena cara mereka dalam menuntut ilmu salah, dan syarat-syaratnya mereka tinggalkan. Barangsiapa salah jalan, tentu tersesat dan tidak akan sampai tujuan. ${ }^{22}$ Oleh karena itu, seorang santri harus mengetahui adab, tata cara dan memenuhi syarat-syaratnya dalam menuntut ilmu, sehingga mereka akan mendapatkan ilmu yang berkah dan bermanfaat. Adab dan tata cara dalam menuntut ilmu tersebut diterangkan di dalam kitab Ta'lim alMuta'allim .

Kitab Ta'lim al-Muta'allim terdiri dari tiga belas bab pokok bahasan. Ketiga belas pokok bahasan tersebut adalah sebagai berikut:

1. Bab ke-1 menerangkan tentang hakikat ilmu, hukum mencari ilmu dan keutamaannya;

2. Bab ke-2 membahas tentang niat dalam mencari ilmu;

\footnotetext{
${ }^{15}$ Syekh Ibrahim bin Ismail, al-Syarh Ta'lim al-Muta'llim, (Indonesia: Maktabah Daar Ihya' al-Kutub al-'Arabiyah, tt), h.1.

${ }^{16}$ Lois Ma'luf, al-Munjid fi al-Lugoh wa al-'A'lam, (Beirut: Dar al-Masyriq, 1975), h. 337.

${ }^{17}$ Imam Al Ghazali, Ihya' Ulumudin, Terj. Moh. Zuhri, Cet. 30, (Semarang: CV. AsySyifa, 2009), h. 171-180.

${ }^{18}$ Ibid, h. 171-180.

${ }^{19}$ Djudi, Konsep Belajar Menurut Al-Zarnuji, (Semarang: Pusat Penelitian Walisongo, 1997), h. 10.

${ }^{20}$ Aly As'ad, Terjemah Ta'limu al-Muta'allim, (Kudus: Menara Kudus, 2007), h. ii.

${ }^{21}$ Abdul Kadir al-Jufri, Terjemah Ta'lim Muta'allim, h. 2.

${ }^{22}$ Ibid.
} 
3. Bab ke-3 membahas tentang cara memilih guru, teman dan ketekunan dalam belajar;

4. Bab ke-4 membahas tentang bagaimana cara menghormati ilmu dan guru;

5. Bab ke-5 membahas tentang kesungguhan dalam mencari ilmu, istiqamah dalam menuntut ilmu dan cita-cita yang luhur;

6. Bab ke-6 membahas tentang ukuran dan urutan dalam menuntut ilmu;

7. Bab ke-7 membahas tentang tawakkal;

8. Bab ke-8 membahas tentang waktu belajar ilmu;

9. Bab ke-9 membahas tentang saling mengasihi dan saling menasehati dalam menuntut ilmu;

10. Bab ke-10 membahas tentang mencari tambahan ilmu pengetahuan;

11. Bab ke-11 membahas tentang bersikap wara' ketika menuntut ilmu;

12. Bab ke-12 membahas tentang hal-hal yang dapat menguatkan hafalan dan yang melemahkannya, dan;

13. Bab ke-13 membahas tentang hal-hal yang mempermudah datangnya rezeki, hal-hal yang dapat memperpanjang umur dan dan yang mengurangi umur. ${ }^{23}$

\section{Tujuan Pembelajaran Kitab Ta'lim al-Muta'allim}

Menurut syekh Az-Zarnuji, tujuan pembelajaran kitab Ta'lim alMuta'allim adalah menjelaskan kepada para santri tentang adab dan tata cara ketika menuntut ilmu, sehingga santri akan memperoleh ilmu yang berkah dan bermanfaat. $^{24}$

Keberhasilan dalam pembelajaran merupakan perubahan positif yang terjadi selama dan sesudah proses pembelajaran dilaksanakan. ${ }^{25}$ Keberhasilan ini antara lain dapat dilihat dari keterlibatan peserta didik secara aktif dalam proses pembelajaran dan perubahan positif yang ditimbulkan sebagai akibat dari proses pembelajaran tersebut. Keterlibatan peserta didik tersebut tidak hanya dilihat dari segi fisiknya, melainkan lebih penting adalah perubahan dari segi intelektual dan emosional selama berlangsungnya kegiatan pembelajaran. Hasil yang diharapkan adalah secara sadar santri akan mengalami perubahan dari pembelajaran tersebut.

Keberhasilan pembelajaran juga dapat dilihat dari segi keberhasilan guru dan segi keberhasilan peserta didik. ${ }^{26}$ Keberhasilan guru, dapat dilihat dari ketepatan guru dalam memilih bahan ajar, media, alat pengajaran, sehingga mampu menghadirkan suasana belajar yang menyenangkan dan menggairahkan, sedangkan keberhasilan peserta didik, dapat dilihat dari timbulnya keinginan yang

${ }^{23}$ Hamam Nashiruddin, Tafhimu al-Muta'allim Fi Tarjamati Ta'limu al-Muta'allim Thariqah at-Ta'allum, (Magelang: Menara Kudus, 1963), h. 8-10.

${ }^{24}$ Ibid, h. 2.

${ }^{25}$ Kasim Yahiji, Cara Mudah Memahami Kitab Gundul, "Strategi Pembelajaran Kitab Kuning di Pondok Pesantren", (Gorontalo: Sultan Amai Press IAIN Sultan Amai Gorontalo, 2011), h. 38 .

${ }^{26}$ Ibid, h. 39. 
kuat pada diri setiap peserta didik untuk belajar mandiri yang mengarah pada peningkatan yang lebih baik dari segi kognitif, afektif, maupun psikomotorik. ${ }^{27}$

Keberhasilan dari segi ini dapat dilihat dari indikasinya pada sejumlah kompetensi yang dimiliki peserta didik setelah mengikuti kegiatan pembelajaran. Contohnya seperti kemampuan mengemukakan berbagai konsep dan teori, kemampuan dalam mempraktekan berbagai teori dan konsep yang dimilikinya, kemampuan dalam berkomunikasi dengan menggunakan bahasa asing baik secara lisan maupun tulisan, peningkatan dalam penghayatan dan pengamalan ajaran agama, dan semakin baik akhlak dan kepribadiannya. ${ }^{28}$

Tujuan pembelajaran kitab Ta'lim al-Muta'allim adalah menjadikan santri agar benar dalam berfikir, benar dalam belajar dan benar dalam pengamalannya, sehingga dengan pembelajaran kitab Ta'lim al-Muta'allim diharapkan santri dapat menjadi pribadi yang berkarakter baik, unggul dalam prestasi dan memegang teguh ajaran Islam.

\section{Urgensi Pembelajaran Kitab Ta'lim al-Muta'allim}

Urgensi pembelajaran kitab Ta'lim al-Muta'allim ini tidak bisa di pungkiri, karena hampir semua pondok pesantren menggunakan kitab tersebut. Menurut Gandung Fajar Panjalu, kitab Ta'lim al-Muta'allim dipelajari hampir disetiap lembaga pendidikan Islam, terutama pendidikan tradisional bahkan pondok pesantren modern di Indonesia. ${ }^{29}$

Pada dasarnya kitab Ta'lim al-Muta'allim lebih menekankan pada pendidikan akhlak yang sangat berpengaruh terhadap motivasi dan penghargaan terhadap ilmu pengetahuan dan ulama, konsep filter terhadap ilmu pengetahuan dan ulama, serta pendekatan-pendekatan teknis pendayagunaan potensi otak, baik dalam terapi alamiah, atau moral psikologis. ${ }^{30}$ Hal ini menunjukkan bahwa pembelajaran kitab Ta'lim al-Muta'allim posisinya sangat penting dalam membentuk karakter dan prestasi belajar santri di dalam pendidikan pondok pesantren.

\section{Metode Pembelajaran Kitab Ta'lim al-Muta'allim}

Menurut Kasim Yahiji, dalam bukunya yang berjudul "Cara Mudah Memahami Kitab Gundul”, bahwa proses pembelajaran merupakan interaksi yang dilakukan antara guru dengan peserta didik dalam suatu pengajaran untuk mewujudkan tujuan yang ditetapkan memerlukan pendekatan yang dijabarkan ke dalam metode pembelajaran. ${ }^{31}$ Metode pembelajaran dapat diartikan cara-cara yang dipergunakan untuk menyampaikan tujuan pembelajaran. ${ }^{32}$ Begitu pula dalam pembelajaran kitab Ta'lim al-Muta'allim , tentunya ada metode yang digunakan untuk menentukan sukses atau tidaknya tujuan pembelajaran tersebut.

27 Ibid.

${ }^{28}$ Ibid, h. 39.

${ }_{29}$ http://www.gfpanjalu.com/2010/02/analisis-kritis-terhadap-kitab-talimul-mut aallim. diakses pada tanggal 13 maret 2017.

${ }^{30}$ Ibid.

${ }^{31}$ Kasim Yahiji, Cara Mudah Memahami, h. 66.

${ }^{32}$ Ibid, h. 68. 
Metode-metode yang digunakan pada pembelajaran kitab Ta'lim al-Muta'allim yang digunakan adalah metode wetonan atau bandongan, sorogan, hafalan, diskusi dan majelis taklim. ${ }^{33}$

a. Metode Bandongan.

Metode bandongan adalah metode pembelajaran kelompok yang diikuti 2 sampai 500 santri. Santri mendengarkan seorang guru atau kiai membaca, menerjemahkan, dan menerangkan isi suatu kitab yang sedang dikajinya. Setiap santri masing-masing membawa kitab yang sama dengan kitab yang sedang baca oleh kiai. Para santri memperhatikan kitabnya sambil mencocokkan bacaannya sebagaimana bacaan kiai dan membuat catatan-catatan kecil, baik pada kertas, buku, maupun pada pinggir kitabnya. ${ }^{34}$ Kata bandongan berasal dari bahasa jawa yang artinya pergi berbondong-bondong secara kelompok. Dalam hal ini seorang guru membacakan dan menjelaskan isi kitab tersebut, sementara santri mendengarkan, memaknai dan menerima. Dalam metode ini, guru berperan aktif sementara murid bersikap pasif. ${ }^{35}$

b. Metode Sorogan.

Metode sorogan adalah metode pembelajaran tradisional yang dilakukan dengan cara seorang santri menyorongkan kitab yang akan dikajinya kepada guru, kemudian santri memohon agar dibimbing mempelajari kitab tersebut. Dalam sistem ini terjadilah proses pembelajaran yang bersifat individual, karena santri dilayani secara personal oleh guru. Santri secara bebas dapat menentukan program kajian, kitab, dan guru sesuai kebutuhan dan kemampuannya. ${ }^{36}$

c. Metode Hafalan.

Metode hafalan adalah metode dimana santri diwajibkan untuk membaca dan menghafal teks-teks bahasa Arab secara individual, guru menjelaskan arti kata demi kata. Metode ini sangat penting pada sistem keilmuan yang lebih mengutamakan argumen naqli, transmisi dan periwayatan (normatif). Metode ini masih relevan untuk diberikan kepada murid-murid usia anak-anak, tingkat dasar dan menengah. ${ }^{37}$

d. Metode Diskusi.

Metode diskusi adalah metode yang dilakukan dengan cara murid atau santri membahasnya bersama-sama melalui tukar pendapat tentang suatu topik yang ada dalam kitab yang dibahas. Dalam kegiatan ini guru bertindak sebagai moderator. Metode ini dapat memacu santri untuk dapat lebih aktif dalam belajar. Melalui metode ini akan tumbuh dan berkembang pemikiran-pemikiran kritis, analisis dan logis. ${ }^{38}$

\footnotetext{
${ }^{33}$ Ibid, h. 69-73.

${ }^{34}$ Ibid, h. 69.

${ }^{35}$ Ibid.

${ }^{36}$ Ibid, h. 69-70.

${ }^{37}$ Ibid, h. 70-71.

${ }^{38}$ Ibid, h. 71
} 


\section{e. Metode Majelis Taklim.}

Metode majlis taklim adalah metode pembelajaran dengan cara ceramah yang biasanya disampaikan dalam kegiatan tabligh atau kuliah umum. Dalam metode ini guru berperan aktif dan murid pasif hanya mendengarkan saja tanpa diberikan kesempatan untuk bertanya. ${ }^{39}$

\section{B. Hubungan Isi Kitab Ta'lim al-Muta'allim dengan Pembentukan Karakter.}

Isi kitab Ta'lim al-Muta'allim memiliki hubungan yang erat dengan pendidikan karakter. Karakter yang dimaksud disini adalah religius (ikhlas), jujur, disiplin, bertanggung jawab, santun, saling menghormati dan saling mengasihi. Hubungan tersebut adalah sebagai berikut:

Pertama, Isi kitab Ta'lim al-Muta'allim yang berhubungan dengan karakter religius (ikhlas) adalah niat mencari ilmu. Setiap santri harus menata niatnya terlebih dahulu sebelum belajar, karena niat adalah pokok dari segala amal ibadah. Banyak amal ibadah yang berupa amal duniawi menjadi amal akhirat karena baiknya niat dan sebaliknya banyak amal ibadah yang tergolong amal ibadah akhirat menjadi amal duniawi karena buruknya niat. ${ }^{40}$ Niat dalam menuntut ilmu adalah ikhlas mengharap ridha Allah, mencari kebahagiaan akhirat, menghilangkan kebodohan, mensyukuri nikmat akal, mensyukuri kesehatan badan, menghidupkan agama dan melestarikan Islam. ${ }^{41}$

Kedua, Isi kitab Ta'lim al-Muta'allim yang berhubungan dengan karakter jujur adalah bersikap wara'. Termasuk sikap wara' ialah tidak membicarakan hal-hal yang tidak berguna. Santri yang bersikap wara' lebih bermanfaat, belajarnya lebih mudah. ${ }^{42}$

Ketiga, Isi kitab Ta'lim al-Muta'allim yang berhubungan dengan karakter disiplin dan bertanggung jawab adalah kesungguhan menuntut ilmu dan istiqamah dalam meraih cita-cita. Santri yang ingin meraih apa yang dicitacitakan, maka ia harus bersungguh-sungguh untuk mencapainya. ${ }^{43}$ Kesungguhan dapat mendekatkan sesuatu yang jauh, dan bisa membuka pintu yang terkunci. ${ }^{44}$

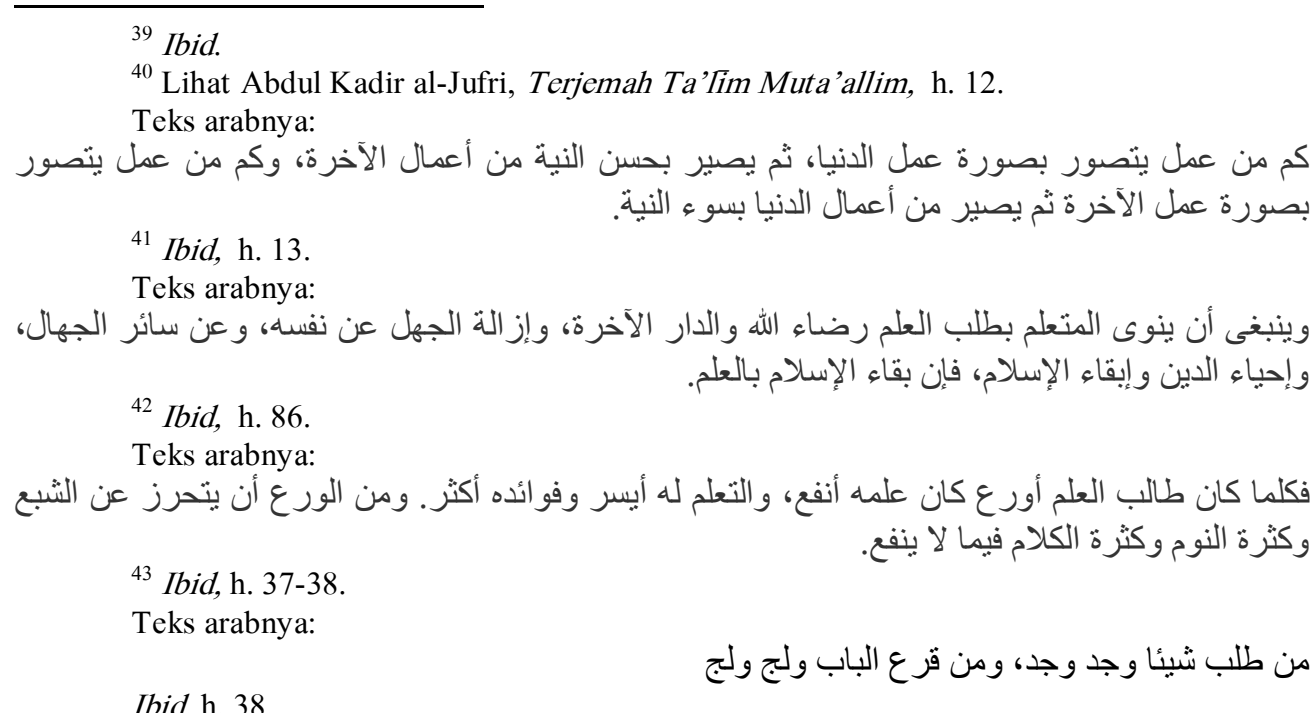


Selain itu, para santri harus menggunakan waktu malamnya ${ }^{45}$ dan masa mudanya untuk belajar. ${ }^{46}$

Keempat, Isi kitab Ta'lim al-Muta'allim yang berhubungan dengan karakter santun adalah ketepatan memilih guru dan teman belajar. Guru yang baik bisa menjadi tauladan ${ }^{47}$ dan teman yang baik akan senantiasa mengajak kepada kebaikan. ${ }^{48}$ Oleh karena itu, santri harus selektif dalam memilih guru dan teman belajar.

Selanjutnya adalah memilih teman belajar. Teman memiliki peranan penting dalam membentuk karakter santri dalam belajar. ${ }^{49}$ Teman yang baik akan memberikan pengaruh yang baik dan sebaliknya. ${ }^{50}$ Di samping itu teman yang buruk akan mengantarkan masuk neraka dan teman yang baik akan mengantarkan masuk ke surga. ${ }^{51}$

Kelima, Isi kitab Ta'lim al-Muta'allim yang berhubungan dengan karakter hormat adalah materi menghormati guru. ${ }^{52}$ Santri tidak akan memperoleh manfaat dari ilmunya apabila ia tidak mau menghormati gurunya. ${ }^{53}$ Cara

\footnotetext{
Teks arabnya:

${ }^{45}$ Ibid, h. 40.

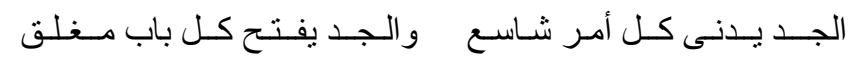

Teks arabnya:

46 Ibid.

مـن شاء أن يحتوى آماله جملا فلـيتخذ لـيله في دركـها جـمـا

Teks arabnya:

${ }^{47}$ Ibid, h. 18.

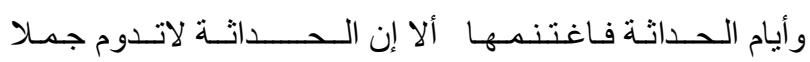

Teks arabnya:

أما اختيار الأستاذ: فينبغى أن يختار الأعلم والأورع والأسن، كما اختار أبو حنيفة، رحم الله عليه، حماد بن

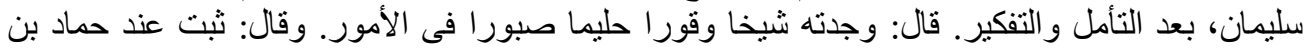

${ }^{48}$ Ibid, h. 24.

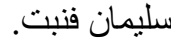

Teks arabnya:

${ }^{49}$ Ibid.

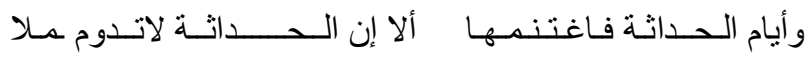

Teks arabnya:

50 Ibid.

فـإن كـان ذا شر فـجنبه سرعـة وإن كان ذا خير فقارنه تهـتى

Teks arabnya:

${ }^{51}$ Ibid, h. 25.

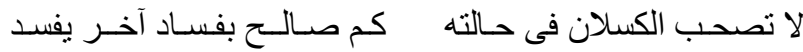

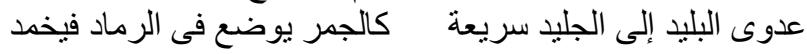

Teks arabnya:

${ }^{52}$ Ibid, h. 26-27.

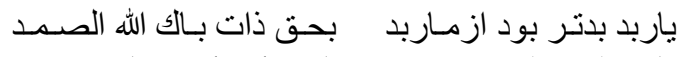

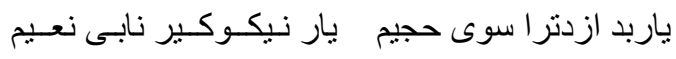

Teks arabnya:

${ }^{53}$ Ibid, h. 26.

$$
\begin{aligned}
& \text { رأيت أحق الحق حق المعلم وأوجبه حفظا على كل مسلم }
\end{aligned}
$$

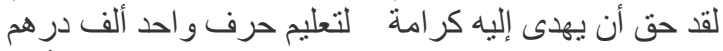

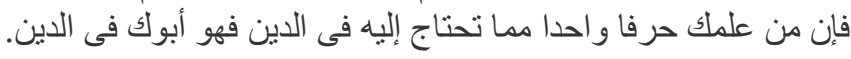


menghormati guru adalah tidak berjalan di depannya, tidak duduk ditempatnya, tidak memulai bicara kecuali ada ijinnya, tidak banyak bicara di hadapan guru, tidak bertanya jika gurunya capek, menjaga waktunya, tidak mengetuk pintunya tapi menunggunya sampai keluar, mencari kerelaan guru, tidak membuatnya marah, mematuhi perintahnya yang tidak bertentangan dengan agama, ${ }^{54}$ menghormati anak-anaknya, dan orang yang ada hubungan kerabat dengannya, tidak duduk dekat dengan gurunya kecuali darurat ketika belajar, santri tidak memilih bidang ilmunya sendiri, akan tetapi menyerahkan kepada gurunya dikarenakan guru lebih tahu mana ilmu yang cocok dengan watak muridnya dan meninggalkan akhlak tercela. ${ }^{55}$ Menghormati guru adalah wajib, karena guru tidak akan memberikan ilmu apabila tidak dihormati. ${ }^{56}$

Keenam, Isi kitab Ta'lim al-Muta'allim yang berhubungan dengan karakter kerjasama adalah musyawarah. Hendaknya santri senantiasa bermusyawarah dalam memecahkan suatu masalah. ${ }^{57}$ Santri yang sempurna

Teks arabnya:

ما وصل من وصل إلا بالحرمة، وما سقط من سقط إلا بترك الحرمة. وقيل: الحرمة خير من الطاعة، ألا

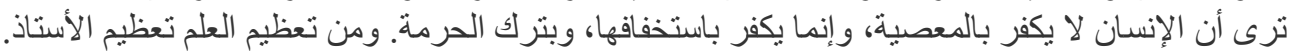
54 Ibid.

Teks arabnya:

55 Ibid, h. 27-30.

قال على رضىى الله عنه: أنا عبد من علمنى حرفا واحدا، إن شاء باع، وإن شاء استرق.

Teks arabnya:

ومن توقير المعلم أن لايمشى أمامه، و لا يجلس مكانه، ولا يبتدئ بالكلام عنده إلا بإذنه، ولا يكثر الكلام عنده، و لا يسأل شيئا عند ملالته وير اعى الوقت، و لا يدق الباب بل يصبر حتى يخرج الأستاذ. فالحاصل: أنه وله يطلب رضاه، ويجتتب سخطه، ويمتثل أمره فى غير معصية لله تعالى، فإنه لا طاعة للمخلوق فى معصية

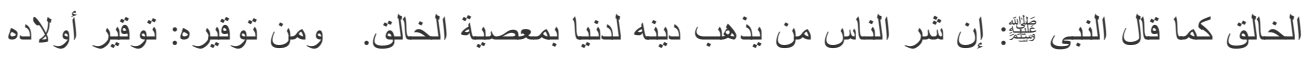
ومن يتعلق به. وكان أستاذنا شيخ الإسلام برهان الدين صاحب الهداية رحمة الله عليه حكى: أن واحدا من أكابر الأئمة بخارى كان يجلس مجلس الدرس، وكان يقوم فى خلال الدرس أحيانا فسألو ا عنه, فقال: إن ابن أستاذى بلعب مع الصبيان فى السكة، ويجيئ أحيانا إلى باب المسجد، فإذا رأيته أقوم لله تعظيما لأستاذى. والقاضى الإمام فخر الدين الأرسابندى كان رئيس الأئمة فى مرو وكان السلطان يحترمه غاية الاحتر ام وكان بقول: إنما وجدت بهذا المنصب بخدمة الأستاذ فإنى كنت أخدم الأستاذ القاضى الإمام أبازيد الدبوسى الإنى وكنت أخدمه و أطبخ طعامه ثنلاثين سنة و لا آكل منه شيئا. فمن تأذى منه أستاذه يحرم بركة العلم ولا ينتفع

${ }^{56}$ Ibid, h. 30. بالعلم إلا قليلا.

Teks arabnya:

${ }^{57}$ Ibid, h. 56-57.

Teks arabnya:

ولا بد لطالب العلم من المذاكرة، والمناظرة، والمطارحة، فينبغى أن يكون كل منها بالإنصاف والتأنى

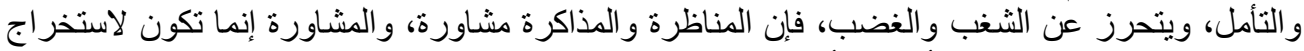

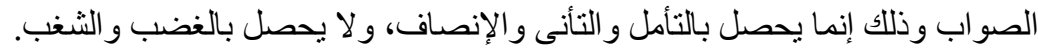


adalah santri yang pendapatnya selalu benar dan mau bermusyawarah. ${ }^{58}$ Segala sesuatu yang diputuskan berdasarkan hasil musyawarah akan menjadi tanggung jawab bersama dan tidak akan saling menyalahkan. ${ }^{59}$

Ketujuh, Isi kitab Ta'lim al-Muta'allim yang berhubungan dengan karakter peduli adalah saling mengasihi. Suasana belajar akan menyenangkan dan tindak pencurian tidak akan terjadi apabila santri saling menyayangi. Pada umumnya, perbuatan baik akan dibalas dengan kebaikan dan sebaliknya. ${ }^{60}$

Kedelapan, Isi kitab Ta'lim al-Muta'allim yang berhubungan dengan karakter saling menyayangi adalah saling mengasihi. Santri akan merasa nyaman dalam belajar apabila mereka saling mengasihi dan menyayangi serta jauh dari prasangka buruk temannya. ${ }^{61}$ Untuk menghindari perkelahian, maka santri harus meninggalkan perbuatan yang menimbulkan permusuhan.

$$
\text { قال عيسى بن مريم صلوات الله عليه: احتملوا من السفيه و احدة كى ثربحوا عشرا. }
$$

Artinya:

Nabi Isa as. berkata, bertahanlah menghadapi ejekan orang yang bodoh sekali saja, niscaya kamu akan beruntung sepuluh kali. ${ }^{62}$

\section{Hubungan Isi Kitab Ta'lim al-Muta'allim dengan Prestasi Belajar.}

Isi kitab Ta'lim al-Muta'allim memiliki hubungan yang erat dengan prestasi belajar. Prestasi yang dimaksud disini adalah prestasi yang memenuhi tiga ranah, yaitu ranah kognitif, afektif dan psikomotorik. Hubungan tersebut adalah sebagai berikut:

Pertama, isi kitab Ta'lim al-Muta'allim yang berhubungan dengan prestasi belajar ranah kognitif adalah ukuran dan urutan belajar dan hal-hal yang menguatkan dan melemahkan hafalan.

Isi kitab Ta'lim al-Muta'allim yang berhubungan dengan prestasi belajar ranah kognitif adalah ukuran dan urutan belajar. Ukuran dan urutan belajar sejalan dengan teori prestasi belajar yaitu ranah kognitif pada indikator ingatan, pemahaman dan analisis dengan kemampuan menunjukkan kembali, dapat

${ }^{58}$ Ibid, h. 20.

Teks arabnya:

${ }^{59}$ Ibid.

الناس تام: من له رأي صنائب ويشاور العقلاء

Teks arabnya:

${ }^{60}$ Ibid, h. 79.

قال على كرم الله وجهه: ما هلك امرؤ عن مشورة.

Teks arabnya:

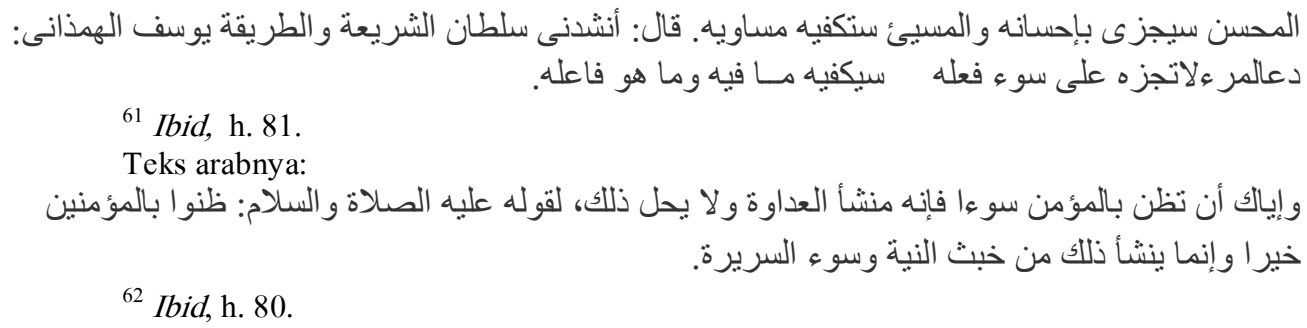


menjelaskan, dapat menguraikan, dan mengklasifikasikan. ${ }^{63}$ Urutan dalam belajar yaitu memulai dari pelajaran yang mudah, kemudian menghafal dan memahami isinya. Setelah paham baru mencatatnya dan menambah sedikit demi sedikit. ${ }^{64}$

Ukuran dalam belajar dijelaskan oleh syekh Syarifudin, bahwa ukuran yang benar dalam belajar adalah memulai dari buku-buku yang mudah dipahami kemudian meningkat kepada buku-buku pada level di atasnya, dan begitu seterusnya. ${ }^{65}$

Berikutnya, isi kitab Ta'lim al-Muta'allim yang berhubungan dengan prestasi belajar ranah kognitif adalah hal-hal yang dapat menguatkan dan melemahkan hafalan. Hal-hal yang menguatkan dan melemahkan hafalan sejalan dengan teori prestasi belajar yaitu ranah kognitif pada indikator ingatan, pemahaman dan analisis dengan kemampuan menunjukkan kembali, dapat menjelaskan, dapat menguraikan, dan mengklasifikasikan. Hal-hal yang dapat menguatkan hafalan adalah rajin belajar, aktif mengurangi makan, shalat malam, membaca shalawat, makan kundar, bersiwak dan membaca al-Qur'an. ${ }^{66}$ Sedangkan hal-hal yang melemahkan hafalan adalah banyak berbuat maksiat, dan berbuat dosa. ${ }^{67}$

Kedua, isi kitab Ta'lim al-Muta'allim yang berhubungan dengan prestasi belajar ranah afektif adalah keutamaan ilmu, niat mencari ilmu, menghormati ilmu, menghormati guru, tawakal, waktu belajar dan bersikap wara' .

Materi keutamaan ilmu sejalan dengan teori prestasi belajar yaitu ranah afektif pada indikator internalisasi atau pendalaman yaitu meyakini dan mengakui

${ }^{63}$ Nana Sudjana, Penilaian Hasil Proses Belajar Mengajar, (Bandung: PT. Remaja Rosdakarya, 2009), h. 22-23.

${ }^{64}$ Lihat Abdul Kadir al-Jufri, Terjemah Ta'Tim Muta'allim, h. 55.

Teks arabnya:

و أنشدنا الثيخ الأجل قوام الدين حماد بن إبراهيم بن إسماعيل الصفار الأنصارى إملاء للقاضى الخليل بن أحمد الشجرى فى ذللك شعر ا: الخماد

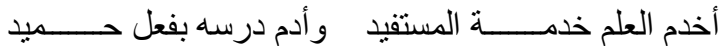

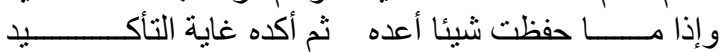

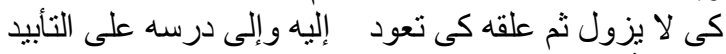

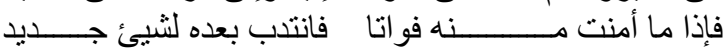

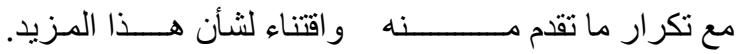

${ }^{65}$ Ibid, h. 54.

Teks arabnya:

وكان الثيخ الإمام الأستاذ شرف الدين العقلى رحمه الله يقول: الصواب عندى فيى هذا ما فعله مشايخنا

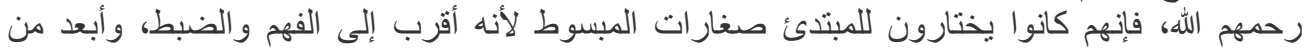
الملالة

${ }^{66} \mathrm{Ibid}$, h. 92.

Teks arabnya:

و أقوى أسباب الحفظ: الجد والمواظبة، وتقليل الغذاء، وصلاة الليل، وقر اءة القرآن من أسباب الحفظ .قيل:

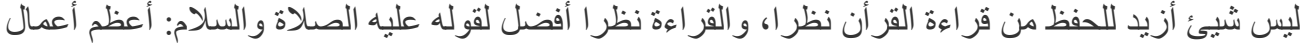

${ }^{67}$ Ibid, h. 93-94.

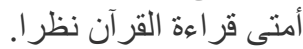

Teks arabnya:

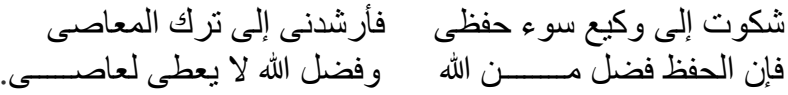


akan pentingnya ilmu. ${ }^{68}$ Pentingnya ilmu pengetahuan sudah tidak diragukan lagi karena ilmu itu hanya dimiliki oleh manusia, sedangkan selain ilmu itu bisa dimiliki manusia dan binatang. Oleh karena itu Allah mengangkat derajat nabi adam di atas para malaikat. ${ }^{69}$ Ilmu merupakan perantara untuk bertakwa, dengan takwa inilah manusia menerima kedudukan mulia di sisi Allah dan keuntungan abadi yaitu surga. ${ }^{70}$

Niat mencari ilmu sejalan dengan teori prestasi belajar yaitu ranah afektif pada indikator internalisasi atau pendalaman yaitu meyakini dan mengakui akan pentingnya niat dalam mencari ilmu. Niat yang benar akan memberikan pengaruh motivasi tersendiri bagi santri dalam meraih prestasi. ${ }^{71}$ Santri yang memiliki niat yang benar, maka apabila ia gagal meraih apa yang dicita-citakan maka tidak akan mudah putus asa dan apabila berhasil tidak akan merasa sombong.

Menghormati ilmu sejalan dengan teori prestasi belajar yaitu ranah afektif pada indikator apresiasi sikap menghargai ilmu. Cara menghormati ilmu adalah menghormati kitabnya, yaitu santri tidak memegang kitab kecuali dalam keadaan suci, ${ }^{72}$ tidak meletakkan kitab di dekat kakinya ketika duduk bersila, ${ }^{73}$ tidak meletakkan sesuatu di atas kitab, ${ }^{74}$ mendengarkan ilmu dan hikmah dengan rasa hormat walaupun sudah mendengar seribu kali, ${ }^{75}$ menulis ilmu dengan tulisan yang baik dan jelas. ${ }^{76}$

${ }^{68}$ Muhibbin Syah, Psikologi Pendidikan dengan Pendekatan Baru, (Bandung: Rosda 2014), h. 150.

${ }^{69}$ Lihat Abdul Kadir al-Jufri, Terjemah Ta'Tim Muta'allim, h. 6.

${ }^{70}$ Ibid, h. 93-94.

Teks arabnya:

${ }^{71}$ Ibid, h. 14.

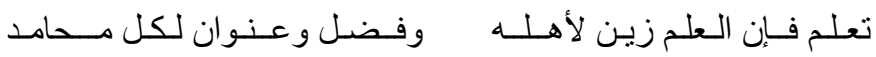

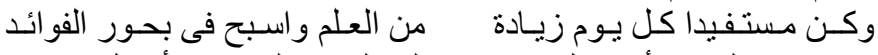

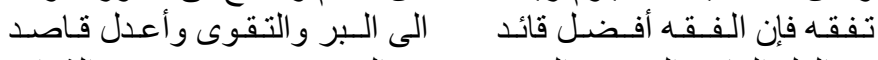

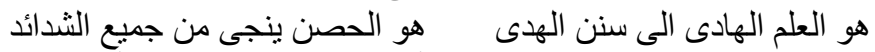

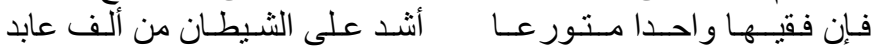

Teks arabnya:

${ }^{72}$ Ibid, h. 32.

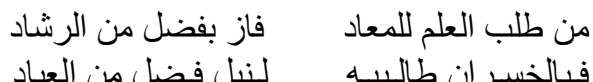

Teks arabnya:

$$
\text { ومن تعظيم العلم: تعظيم الكتاب، فينبغى لطالب العلم أن لا يأخذ الكتاب إلا بطهارة. }
$$

${ }^{73}$ Lihat Abdul Kadir al-Jufri, Terjemah Ta'Tim Muta'allim, h. 32.

Teks arabnya:

$$
\begin{aligned}
& \text { ومن التعظيم الو اجب للعالم أن لا يمد الرجل إلى الكتاب ويضع كتاب التفسير فوق سائر الكتب تعظيما ولا } \\
& { }^{74} \text { Ibid, h. } 32 . \\
& \text { يضع شيئا آخر على الكتاب. } \\
& \text { Teks arabnya: } \\
& \text { وكان أستاذنا الثيخ برهان الدين رحمه الله تعالى يحكى عن شيخ من المشايخ: أن فقيها كان وضع المحبرة }
\end{aligned}
$$

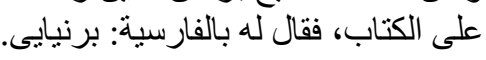

Teks arabnya: 
Menghormati guru sejalan dengan teori prestasi belajar yaitu ranah afektif pada indikator apresiasi sikap menghargai guru akan menumbuhkan sikap harmonis. ${ }^{77}$ Ali bin Abi Thalib yang terkenal dengan kepandaiannya mengatakan bahwa dirinya adalah budak dari orang yang mengajarnya. ${ }^{78}$ Santri yang tidak menghormati gurunya, maka ilmunya tidak akan diberkahi. ${ }^{79}$

Tawakal sejalan dengan teori prestasi belajar yaitu ranah afektif pada indikator penerimaan dengan menunjukkan sikap menerima apabila tidak memperoleh hasil yang tidak sesuai dengan keinginan. ${ }^{80}$ Santri harus senantiasa tawakal dan berserah diri kepada Allah pada saat menuntut ilmu dan tidak perlu mencemaskan masalah rezeki. ${ }^{81}$

Waktu belajar sejalan dengan teori prestasi belajar yaitu ranah afektif pada indikator apresiasi sikap menganggap penting waktu belajar. ${ }^{82}$ Hendaknya para santri mempergunakan seluruh waktunya untuk belajar. Waktu yang baik untuk digunakan belajar adalah antara maghrib sampai isya' dan waktu subuh. ${ }^{83}$

Bersikap wara' sejalan dengan teori prestasi belajar yaitu ranah afektif pada indikator karakteristik dengan menjelmakan diri dalam pribadi dan perilaku sehari-hari. ${ }^{84}$ Bersikap wara' adalah menjaga diri dari hal-hal yang tidak jelas halal haramnya ketika menuntut ilmu. ${ }^{85}$

Ketiga, isi kitab Ta'lim al-Muta'allim yang berhubungan dengan prestasi belajar ranah psikomotorik adalah mencari tambahan ilmu dan kesungguhan dalam menuntut ilmu. Mencari tambahan ilmu sejalan dengan teori

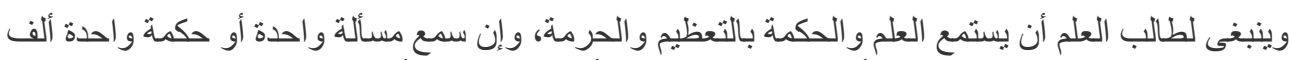
مرة. وقيل: من لم يكن تعظيمه بعد ألف مرة كتعظيمه في أول مرة فليس بأهل ألهل العلم.

${ }^{76} \mathrm{Ibid}$, h. 31.

Teks arabnya:

ور أى أبو حنبفة رحمه الله تعالى كتابا يقرمط فى الكتابة فقال: لا تقرمط خطلك، إن عشت تندم و إن مت تشتن. يعنى إذا شخت وضعف نور بصرك ندمت على ذلك.

${ }^{77}$ Muhibbin Syah, Psikologi Pendidikan, h. 150.

${ }^{78}$ Lihat Abdul Kadir al-Jufri, Terjemah Ta'Tim Muta'allim, h. 26.

Teks arabnya:

${ }^{79}$ Ibid, h. 30.$$
\text { قال على رضى الله عنه: أنا عبد من علمنى حرفا واحدا، إن شاء باع، وإن شاء استرق. }
$$

Teks arabnya:

${ }^{80}$ Muhibbin Syah, Psikologi Pendidikan, h. 150.

فمن تأذى منه أستاذه يحرم بركة العلم و لا ينتفع بالعلم إلا قليا.

${ }^{81}$ Lihat Abdul Kadir al-Jufri, Terjemah Ta'Tim Muta'allim, h. 71.

Teks arabnya:

روى أبو حنيفة رحمه الله عن عبد الله بن الحارث الزبيدى صاحب رسل الله صلى الله عليه و سلم: من تفقه فى دين الله كفى همه الله تعالى ورزقة من حيث لاله بن لا يحتسب.

${ }^{82}$ Muhibbin Syah, Psikologi Pendidikan, h. 150.

${ }^{83}$ Lihat Abdul Kadir al-Jufri, Terjemah Ta'Tim Muta'allim, h. 71.

Teks arabnya:

${ }^{84}$ Muhibbin Syah, Psikologi Pendidikan, h. 150.

و أفضل الأوقات شرخ الثباب، ووقت السحر ، وما بين العشائين.

${ }^{85}$ Lihat Abdul Kadir al-Jufri, Terjemah Ta'Tim Muta'allim, h. 86.

Teks arabnya:

فكلما كان طالب العلم أورع كان علمه أنفع، والتعلم له أيسر وفو ائده أكثر. ومن الورع أن يتحرز عن الثبع

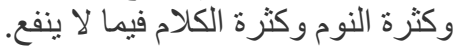


prestasi belajar yaitu ranah psikomotorik pada indikator keterampilan bergerak dan bertindak dengan mengkoordinasikan gerak mata, tangan, kaki, dan anggota tubuh lainnya. ${ }^{86}$ Santri hendaknya senantiasa menambah ilmu setiap hari agar mendapat kemuliaan. Santri harus selalu membawa buku dan puplen untuk menulis ilmu yang bermanfaat yang ia dengar setiap saat. ${ }^{87}$

Kesungguhan dalam mencari ilmu sejalan dengan teori prestasi belajar yaitu ranah psikomotorik pada indikator keterampilan bergerak, bertindak, dan kecakapan ekspresi verbal atau non verbal. ${ }^{88}$ Santri yang ingin meraih apa yang dicita-citakan, maka ia harus bersungguh-sungguh untuk mencapainya ${ }^{89}$ dan menggunakan waktu malamnya dan masa mudanya untuk belajar. ${ }^{90}$

$$
\text { من طلب شيئا وجد وجد، ومن قرع الباب ولج ولج }
$$

Artinya:

Barang siapa yang bersungguh-sungguh mencari sesuatu, tentu ia akan mendapatkannya. Dan siapa saja yang mau mengetuk pintu dan maju terus, tentu ia akan masuk. ${ }^{91}$

\section{Pendidikan Karakter.}

Dari segi bahasa, pendidikan dapat diartikan sebagai perbuatan, hal, cara, mendidik, pengetahuan mendidik, pemeliharaan badan, batin dan sebagainya. ${ }^{92}$ John Dewey merumuskan "Education is all one growing; its has no end beyond it self" (Pendidikan adalah segala sesuatu bersamaan dengan pertumbuhan, pendidikan sendiri tidak punya tujuan akhir dibalik dirinya). ${ }^{93}$ Menurut Marimba dalam bukunya "Metodologi Pengajaran Agama Islam" mendefinisikan pendidikan sebagai bimbingan secara sadar pendidik terhadap perkembangan jasmani dan ruhani menuju terbentuknya kepribadian yang utama. ${ }^{94}$ Dari definisi di atas, maka pengertian pendidikan adalah suatu proses

\footnotetext{
${ }^{86}$ Muhibbin Syah, Psikologi Pendidikan, h. 150.

${ }^{87}$ Lihat Abdul Kadir al-Jufri, Terjemah Ta'Tim Muta'allim, h. 82-83.

Teks arabnya:

من حفظ فر ومن كتب قر. وقيل: العلم ما يؤخذ من أفواه الرجال، لأنهم يحفظون أحسن ما بيمعون،

${ }^{88}$ Muhibbin Syah, Psikologi Pendidikan, h. 150.

ويقولون أحسن ما بحفظون.

${ }^{89}$ Lihat Abdul Kadir al-Jufri, Terjemah Ta'Tim Muta'allim, h. 38.

Teks arabnya:

${ }^{90}$ Ibid, h. 40.

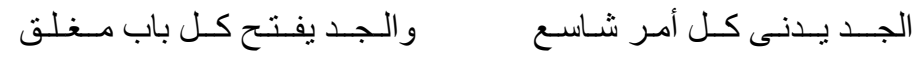

Teks arabnya:

${ }^{91}$ Ibid, h. 37-38.

92 Zain Mubarak, Membumikan Pendidikan Nilai, (Bandung: Alfabeta, 2009), h. 1.

${ }^{93}$ Kartono Kartini, Tinjauan Holistik Mengenai Tujuan Pendidikan Nasional, (Jakarta: Paradnya Paramita, 1997), h. 3.

94 Ahmad Tafsir, Metodologi Pedidikan Agama Islam, (Bandung: PT. Remaja Rosdakarya Offset, 2008), h. 6.
} 
menanamkan dan mengembangkan pada diri peserta didik tentang hidup, sikap dalam hidup agar kelak ia dapat membedakan barang yang benar dan yang salah, yang baik dan yang buruk, sehingga kehadirannya ditengah-tengah masyarakat akan bermakna dan berfungsi secara optimal. ${ }^{95}$

Istilah karakter secara khusus dipakai dalam konteks pendidikan muncul pada akhir abad 18 dan pertama kali dicetuskan F.W. Foerster. ${ }^{96}$ Karakter berasal dari bahasa latin yaitu "kharakter", "kharassein", "kharax". Dalam bahasa Inggris "character", dalam bahasa Yunani "charassein" dan dalam bahasa Indonesia adalah karakter. ${ }^{97}$ Menurut bahasa, karakter adalah tabiat atau kebiasaan, sedangkan menurut istilah, karakter adalah kepribadian, ciri, karakteristik, gaya, sifat khas dari diri seseorang. ${ }^{98}$

Wynne mengemukakan pendapat bahwa karakter berasal dari bahasa Yunani yang berarti "to mark" (menandai) dan memfokuskan pada bagaimana menerapkan nilai-nilai kebaikan dalam tindakan nyata atau perilaku sehari hari. ${ }^{99}$ Menurut Hornby dan Parnwell, karakter adalah kualitas mental atau moral, kekuatan moral, nama atau reputasi. ${ }^{100}$ Menurut Joel Kuperman, karakter bermakna instrumen for making dan graving, impres, stamp, distinctive nature. ${ }^{101}$ Menurut Hermawan Kertajaya, karakter adalah ciri khas yang dimiliki oleh suatu benda atau individu, ${ }^{102}$ sedangkan menurut Dirjen Pendidikan Agama Islam Kementerian Agama Republik Indonesia (2010), karakter diartikan sebagai totalitas ciri-ciri pribadi yang melekat dan dapat diidentifikasi pada perilaku individu yang bersifat unik, dalam arti secara khusus ciri-ciri ini membedakan antara satu individu dengan yang lainnya. ${ }^{103}$ Dari definisi di atas, maka pengertian karakter adalah sifat-sifat kejiwaan, akhlak atau budi pekerti yang membedakan masing-masing individu dengan individu lainnya.

Menurut Thomas Lickona (1991) pendidikan karakter adalah pendidikan untuk membentuk kepribadian seseorang melalui pendidikan budi pekerti, yang hasilnya terlihat dalam tindakan nyata seseorang, yaitu tingkah laku yang baik, jujur, bertanggung jawab, menghormati orang lain, kerja keras, dan sebagainya. ${ }^{104}$ Elkind dan Sweet memberikan definisi pendidikan karakter adalah upaya yang disengaja untuk membantu manusia, peduli dan inti atas nilai-

${ }^{95}$ Zamroni, Pengantar Pengembangan Teori Sosial, (Yogyakarta: Tiara Wacana, 1992), h. 9 .

${ }^{96}$ Doni Koesoema A., Pendidikan Karakter; Strategi Mendidik Anak di Zaman Modern, (Jakarta: PT. Grasindo, 2007), h. 79.

97 Abdullah Majid, Dian Andayani, Pendidikan Karakter Perspektif Islam, cet. II (Bandung: PT. Rosda Karya, 2012), h. 11.

${ }^{98}$ Sjarkawi, Pembentukan Kepribadian Anak; Peran Moral, Intelektual, Emosional, dan Sosial Sebagai Wujud Membangun Jatidiri, (Jakarta: PT. Bumi Aksara, 2006), h. 11.

${ }^{99}$ Mulyasa, Manajemen Pendidikan Karakter, (Jakarta: Bumi Aksara, 2013), h. 3.

${ }^{100}$ Abdullah Majid, Dian Andayani, Pendidikan Karakter, h. 11.

${ }^{101}$ Zubaedi, Desain Pendidikan Karakter (Konsepsi dan Aplikasinya Dalam Lembaga Pendidikan), (Jakarta: Kencana Prenada Media Group, 2011), h. 12.

${ }^{102}$ Ibid.

${ }^{103}$ Mulyasa, Manajemen Pendidikan Karakter, h. 4.

${ }^{104}$ Heri Gunawan, Pendidikan Karakter (Konsep dan Implikasinya), (Bandung: Alfabeta: 2014), h. 23. 
nilai etis atau susila. Dimana kita berpikir tentang macam-macam karakter yang kita inginkan untuk anak kita, ini jelas bahwa kita ingin mereka mampu untuk menilai apa itu kebenaran, sangat peduli tentang apa itu kebenaran atau hak-hak, dan kemudian melakukan apa yang mereka percaya menjadi yang sebenarnya, bahkan dalam menghadapi tekanan dari dan tanpa dalam godaan.

Character education is the deliberate effort to help people understand, care about, and act upon core ethical values. When we thing about the kind of character we want for our children, it is clear that we want them to be able to judge what is right, care deeply about what is right, and then do what they believe to be right, even in the face of pressure from without and temptation from within. ${ }^{105}$

Pendidikan karakter adalah suatu proses menanamkan dan mengembangkan pada diri peserta didik tentang sifat batin manusia yang mempengaruhi segenap pikiran dan perbuatannya sehingga membedakan antara individu yang satu dengan individu yang lain.

\section{Tujuan pendidikan karakter.}

Menurut Socrates tujuan dasar pendidikan karakter adalah untuk membuat seseorang menjadi baik dan cerdas. ${ }^{106}$ Martin Luther King menyatakan bahwa tujuan pendidikan karakter adalah melahirkan insan cerdas dan berkarakter kuat. ${ }^{107}$ Mulyasa menyatakan di dalam bukunya yang berjudul "Manajemen Pendidikan Karakter", bahwa pendidikan karakter bertujuan untuk meningkatkan mutu proses dan hasil pendidikan yang mengarah pada pembentukan karakter dan akhlak mulia peserta didik secara utuh, terpadu dan seimbang sesuai dengan standar kompetensi lulusan pada setiap satuan pendidikan. ${ }^{108}$ Melalui pendidikan karakter peserta didik diharapkan mampu secara mandiri meningkatkan dan pengetahuannya, mengkaji dan menginternalisasikan serta mempersonalisasikan nilai-nilai karakter dan akhlak mulia sehingga terwujud dalam perilaku sehari-hari. ${ }^{109}$

Merujuk pada pernyataan Socrates dan Martin, maka tujuan pendidikan karakter adalah menciptakan manusia yang baik, cerdas dan berkarakter.

2. Pilar-Pilar Pendidikan Karakter. ${ }^{110}$

1. Moral Knowing.

105 Ibid.

${ }^{106}$ Abdullah Majid, Dian Andayani, Pendidikan Karakter, h. 30.

${ }^{107}$ Maksudin, Pendidikan Karakter Non-Dikotomik, Yogyakarta: Pustaka Pelajar, 2013

h. 58 .

${ }^{108}$ Mulyasa, Manajemen Pendidikan Karakter, h. 9.

109 Ibid.

${ }^{110}$ Abdullah Majid, Dian Andayani, Pendidikan Karakter, h. 31-36. 
William Kilpatrick menyebutkan salah satu penyebab ketidakmampuan seseorang berbuat baik meskipun ia telah memiliki pengetahuan tentang kebaikan itu dikarenakan ia tidak terlatih untuk melakukan kebaikan. Berangkat dari pemikiran ini, maka kesuksesan pendidikan karakter sangat bergantung pada ada dan tidaknya knowing, loving dan doing action dalam penyelenggaraan pendidikan karakter.

Moral knowing sebagai aspek pertama memiliki enam unsur, yaitu: kesadaran moral, pengetahuan tentang nilai-nilai moral, logika moral, keberanian menentukan sikap, dan pengenalan diri. Keenam unsur ini adalah komponenkomponen yang harus diajarkan kepada siswa untuk mengisi ranah pengetahuan mereka.

\section{Moral Loving}

Moral Loving merupakan penguatan aspek emosi siswa untuk menjadi manusia berkarakter. Penguatan ini berkaitan dengan bentuk-bentuk sikap yang harus dirasakan oleh siswa, yaitu percaya diri, peka terhadap penderitaan orang lain, cinta kebenaran, pengendalian diri dan kerendahan hati.

Seseorang yang memiliki kemampuan moral kognitif yang baik tidak saja menguasai bidangnya, tetapi memiliki dimensi rohani yang kuat. Keputusankeputusannya menunjukkan warna kemahiran seorang profesional yang didasarkan pada sikap moral atau akhlak yang luhur.

\section{Moral Doing.}

Fitrah manusia sejak lahir adalah memerlukan orang lain. Manusia tidak bisa berkembang baik kecuali ada kehadiran orang lain. Kehadiran seseorang di tengah-tengah orang lain harus memberikan manfaat bagi orang lain. Untuk mampu memberikan manfaat kepada orang lain, maka setiap individu harus mempunyai kemampuan dan keterampilan.

\section{Ciri-Ciri Pendidikan Karakter.}

Menurut Foester, ada empat ciri dasar dalam pendidikan karakter, yaitu; ${ }^{111}$

1) Keteraturan interior adalah dimana setiap tindakan diukur berdasarkan hirarki nilai. Nilai menjadi pedoman normatif setiap tindakan.

2) Koherensi adalah keberanian yang membuat seseorang teguh pada prinsip dan tidak mudah terombang ambing pada situasi baru. Koherensi merupakan dasar yang membangun rasa percaya satu satu sama lain. Tidak adanya koherensi dapat meruntuhkan kredibilitas seseorang.

3) Otonomi adalah dimana seseorang menginternalisasikan aturan dari luar sampai menjadi nilai-nilai pribadi. Ini dapat dilihat melalui penilaian atas keputusan pribadi tanpa terpengaruh desakan orang lain.

4) Keteguhan dan kesetiaan. Keteguhan merupakan daya tahan seseorang guna menginginkan apa yang dipandang baik, dan

${ }^{111}$ Ibid. h. 36-38. 
kesetiaan merupakan dasar bagi penghormatan atas komitmen yang dipilih.

Kematangan empat karakter di atas memungkinkan manusia melewati tahap individualitas dan personalitas, antara aku alami dan aku rohani, antara independensi eksterior dan interior. Karakter inilah yang menentukan performa seseorang dalam segala tindakannya.

\section{Nilai-Nilai Karakter. ${ }^{112}$}

Menurut Djahiri, nilai adalah suatu jenis kepercayaan yang letaknya berpusat pada sistem kepercayaan seseorang tentang bagaimana seseorang sepatutnya dalam melakukan sesuatu, atau apa yang berharga dan tidak berharga untuk dicapai. ${ }^{113}$ Sumantri mendefinisikan nilai adalah hal yang terkandung dalam diri (hati nurani) manusia yang lebih memberi dasar pada prinsip akhlak yang merupakan standar dari keindahan dan efisiensi atau keutuhan kata hati. ${ }^{114}$

Indonesian Heritage Foundation, merumuskan sembilan nilai karakter dasar yang menjadi tujuan pendidikan karakter, yaitu; 1). Cinta kepada Allah dan semesta beserta isinya; 2). Tanggung jawab, disiplin dan mandiri; 3). Jujur; 4). Hormat dan santun; 5). Kasih sayang, peduli dan kerjasama; 6). Percaya diri, kreatif, kerja keras dan pantang menyerah; 7). Keadilan dan kepemimpinan; 8). Baik dan rendah hati; dan 9). Toleransi, cinta damai dan persatuan.

Character Counts di Amerika mengidentifikasi nilai karakter ada sepuluh, yaitu; 1). Trustworthines (dapat dipercaya); 2). Respect (rasa hormat dan perhatian); 3). Responsibility (tanggung jawab); 4). Fairnes (jujur); 5). Caring (peduli); 6). Citizenship (kewarganegaraan); 7). Honesty (ketulusan); 8). Courage (berani); 9). Diligence (tekun); dan 10). Integrity (integritas).

Ari Ginanjar dengan teori ESQ menyodorkan pemikiran bahwa setiap karakter positif sesungguhnya akan merujuk kepada sifat-sifat mulia Allah. Dari sekian banyak karakter tersebut, Ari merangkumnya dalam tujuh karakter dasar, yaitu; 1). Jujur; 2). Tanggung jawab; 3). Disiplin; 4). Visioner; 5). Adil; 6). Peduli; dan 7). Kerjasama.

\section{Proses Pembentukan Karakter.}

Secara alami, anak sejak lahir hingga berumur lima tahun belum memiliki kemampuan menalar. Mereka tumbuh dengan nalar di bawah alam sadar, masih terbuka menerima informasi apa saja dan stimulus yang dimasukkan ke dalamnya tanpa ada penyeleksian, mulai dari orang tua dan lingkungan keluarga. ${ }^{115}$ Dari situlah pondasi awal terbentuknya karakter anak.

${ }^{112}$ Ibid. h. 42-56.

${ }^{113}$ Heri Gunawan, Pendidikan Karakter, h. 31.

114 Ibid.

115 Syamsul Kurniawan, Pendidikan Karakter : Konsepsi \& Implementasinya Secara Terpadu Di Lingkungan Keluarga, Sekolah, Perguruan Tinggi, \& Masyarakat, (Yogyakarta: ArRuzz, 2013), h. 43. 
Tahapan pendidikan karakter anak berikutnya adalah pendidikan di lingkungan sekolah. ${ }^{116}$ Peran sekolah memiliki andil yang besar dalam pembentukan karakter anak. Pada tahapan ini anak sudah mulai berinteraksi dengan situasi sosial yang lebih luas. Diantaranya adalah anak dituntut untuk berinteraksi dengan anak lainnya. Di sini anak memperoleh pengalaman baru, berupa teman baru yang memiliki latar belakang pendidikan keluarga yang berbeda-beda. Hal ini secara langsung maupun tidak langsung akan mempengaruhi karakter anak. Peran sekolah yang paling dominan dalam membentuk karakter anak adalah guru. ${ }^{117}$ Pembentukan karakter yang dilakukan guru adalah melalui proses pembelajaran dan keteladanan. ${ }^{118}$

Tahapan pendidikan karakter yang terakhir adalah di lingkungan masyarakat. ${ }^{119}$ Setelah anak mendapatkan pendidikan di lingkungan keluarga dan sekolah, maka anak akan berbaur dengan lingkungan masyarakat. Masyarakat memiliki peranan yang sangat besar dalam pembentukan karakter anak. ${ }^{120}$ Anak secara langsung akan diperhadapkan pada situasi sosial yang lebih luas dan heterogen. Anak akan bergaul dengan siapapun tanpa batas mulai dari anak-anak, teman sejawat dan orang yang lebih tua. Anak akan mendapatkan pengalaman baru dengan melihat secara langsung perilaku masyarakat. Lingkungan masyarakat yang baik, akan membentuk karakter anak cenderung berperilaku baik dan sebaliknya.

Selanjutnya, semua pengalaman hidup yang berasal dari lingkungan keluarga, sekolah, lingkungan dan berbagai sumber lainnya yang menambah pengetahuan akan mengantarkan seseorang memiliki kemampuan yang semakin besar untuk dapat menganalisis dan menalar objek luar. Mulai dari sinilah pikiran sadar menjadi semakin dominan. Seiring perjalanan waktu, maka peyaringan terhadap informasi yang masuk melalui pikiran sadar menjadi lebih ketat. Informasi yang masuk melalui pancaindera dapat dengan mudah diterima oleh pikiran bawah sadar. Selain itu, faktor yang paling penting dan berdampak pada karakter adalah makanan, teman, orang tua dan tujuan hidup yang merupakan faktor terkuat dalam mewarnai karakter seseorang. ${ }^{121}$ Oleh karena itu, proses pembentukan karakter harus dimulai dari lingkungan keluarga, sekolah dan lingkungan.

\section{Implementasi Pembentukan Karakter}

Pada umumnya pendidikan karakter menekankan pada keteladanan, penciptaan lingkungan dan pembiasaan. ${ }^{122}$ Dengan demikian, apa yang dilihat, didengar, dirasakan dan dikerjakan oleh anak dapat membentuk karakter mereka.

116 Moh. Haitami Salim dan Syamsul Kurniawan, Studi Ilmu Pendidikan Islam, (Yogyakarta: Ar-Ruzz Media, 2012), h. 268.

117 Ahmad D. Marimba, Pengantar Filsafat Pendidikan Islam, (Bandung: Remaja Rosdakarya, 1989), h.37.

${ }_{118}$ Mulyasa, Manajemen Pendidikan Karakter, h. 63.

${ }^{119}$ Syamsul Kurniawan, Pendidikan Karakter, h, 49.

${ }^{120}$ Moh. Haitami Salim dan Syamsul Kurniawan, Studi Ilmu Pendidikan, h. 271.

121 Abdullah Munir, Pendidikan Karakter, (Yogyakarta: al-Ma'arif, 2010), h. 9.

${ }^{122}$ Mulyasa, Manajemen Pendidikan Karakter, h. 9. 
Menurut Budiman, secara koheren, karakter memancar dari hasil olah pikir, olah rasa dan karsa serta olah raga yang mengandung nilai, kemampuan, kapasitas moral dan ketegaran dalam menghadapi kesulitan dan tantangan. ${ }^{123}$ Secara psikologis, karakter individu dimaknai sebagai hasil keterpaduan empat bagian, yakni olah hati, olah pikir, olah rasa dan olah raga, sehingga menghasilkan enam karakter ut ama dalam seorang individu, yaitu jujur, tanggung jawab, cerdas bersih, sehat, peduli, dan kreatif. ${ }^{124}$ Keberhasilan pendidikan karakter di sekolah dapat diketahui dari berbagai perilaku sehari-hari yang tampak dalam setiap aktivitas yang menunjukkan kesadaran, kejujuran, keikhlasan, kesederhanaan, kemandirian, kepedulian, kebebasan dalam bertindak, kecermatan atau ketelitian dan komitmen. ${ }^{125}$

\section{E. Prestasi Belajar}

Prestasi belajar adalah sebuah kalimat yang terdiri dari dua kata, yaitu prestasi dan belajar. Untuk memahami tentang prestasi belajar, maka kita harus mengetahui lebih dahulu tentang definisi prestasi belajar.

Menurut Kamus Umum Poerwadarminta, prestasi adalah hasil yang telah dicapai (dilakukan, dikerjakan dan sebagainya). ${ }^{126}$ Menurut Saiful Bahri Djamarah, prestasi adalah apa yang telah dapat diciptakan, hasil pekerjaan, hasil menyenangkan hati yang diperoleh dengan jalan keuletan kerja baik secara individu maupun kelompok. ${ }^{127}$

Menurut Hintzman, "Learning is a change in organism due to experience which can affect the organism"s behavior", (belajar adalah proses perubahan tingkah laku). ${ }^{128}$ Menurut Hilgard, E.R., belajar adalah suatu proses timbul atau berubahnya tingkah laku melalui latihan itu sendiri.

"Learning is the process by which an activity originates or is changed through responding to a situation, provided the changes can not be attributed to growth or the temp orary state of the organism as in fatique or under drugs". ${ }^{129}$

Pendapat Hilgrad ini dirumuskan lebih operasional oleh James $\mathrm{O}$ Whittaker, yaitu "Learning may be defined as the process by with behavior organites or is altered through training or experience". Menurut Whittaker, belajar adalah terjadinya perubahan tingkah laku (hasil dari pendidikan). Perubahan tingkah laku akibat pertumbuhan fisik atau kematangan, kelelahan,

123 Ibid, h. 164.

${ }^{124}$ Ibid.

${ }^{125}$ Mulyasa, Manajemen Pendidikan Karakter, h. 12.

${ }^{126}$ Poerwadarminta, Kamus Umum Bahasa Indonesia, (Jakarta: PN. Balai Pustaka, 1985), h. 768.

${ }^{127}$ Saiful Bahri Djamarah, Perstasi Belajar dan Kompetensi Guru, 1994), h. 21-22. 2014), h. 88

${ }^{128}$ Muhibbin Syah, Psikologi Pendidikan dengan Pendekatan Baru, (Bandung: Rosda

${ }^{129}$ Sumardi Surya Brata, Psikologi Pendidikan, (Jakarta: Raja Grafindo Persada, 1998), h. 232 . 
penyakit, atau karena menelan obat-obatan tidak tergolong kepada belajar. ${ }^{130}$ Menurut Skinner, belajar adalah tingkah laku, pada saat subjek belajar maka responnya meningkat, kebalikannya (unlearning) jika subjeknya tidak belajar maka responnya akan menurun. ${ }^{131}$ Maka belajar didefinisikan sebagai suatu perubahan dalam kemungkinan atau peluang terjadinya respon. ${ }^{132}$

Menurut I.L Pasaribu dan B. Simanjuntak menyatakan bahwa "prestasi belajar adalah isi dan kapasitas seseorang. Maksudnya adalah hasil yang diperoleh seseorang setelah mengikuti pendidikan ataupun pelatihan tertentu. Ini bisa ditentukan dengan memberikan tes pada akhir pendidikan itu. ${ }^{133}$

Menurut Suratinah Tirtonegoro, mengartikan prestasi belajar sebagai penilaian hasil usaha kegiatan belajar yang dinyatakan dalam bentuk simbol, angka, huruf, maupun kalimat yang dapat mencerminkan hasil yang sudah dicapai oleh setiap anak dalam periode tertentu. ${ }^{134}$ Menurut Muhibbin Syah, prestasi belajar diartikan sebagai tingkat keberhasilan siswa mencapai tujuan yang telah ditetapkan dalam sebuah program pengajaran. ${ }^{135}$

Berdasarkan definisi di atas, maka pengertian prestasi belajar adalah hasil belajar atau perubahan tingkah laku yang menyangkut ilmu pengetahuan, keterampilan dan sikap setelah melalui proses tertentu, sebagai hasil pengalaman individu dalam interaksi dengan lingkungannya. ${ }^{136}$

\section{Macam-macam Prestasi Belajar.}

Menurut Bloom dkk. mengkategorikan prestasi belajar kedalam tiga ranah, yaitu: 1). Ranah kognitif, meliputi kemampuan pengetahuan, pemahaman, penerapan, analisis, sintesis, dan evaluasi; 2). Ranah afektif, meliputi prilaku penerimaan, sambutan, penilaian, organisasi dan karakterisasi; 3). Ranah psikomotorik meliputi kemampuan motorik berupa persepsi, kesiapan, gerakan terbimbing, gerakan terbiasa, gerakan kompleks, penyesuaian pola gerakan dan kreativitas. $^{137}$

\section{Faktor-Faktor Yang Mempengaruhi Prestasi Belajar.}

Menurut Slameto mengemukakan bahwa ada beberapa faktor yang mempengaruhi prestasi belajar banyak jenisnya tetapi dapat digolongkan menjadi

\footnotetext{
${ }^{130}$ Masrial, Teras Kuliah Belajar Mengajar, (Padang: Angkasa Raya, 1993), h. 8.

${ }^{131}$ Dimyati, Mudjiono, Belajar dan Pembelajaran, (Jakarta: Rineka Cipta, 2009), h. 9.

${ }^{132}$ Marget E Bell Gredlen, Belajar dan Membelajarkan, (Jakarta: Rajawali Pers, 1991), h.

118.

133 I. L. Pasaribu dan B. Simandjuntak, Metode Belajar dan Kesulitan Belajar, (Bandung: Tarsito, 1983), h. 91.

${ }^{134}$ Sutratinah Tirtonegoro, Anak Super Normal dan Program Pendidikannya, (Jakarta: Bina Aksara, 2001), h. 43.

${ }^{135}$ Muhibbin Syah, Psikologi Pendidikan Dengan Pendekatan Baru, (Bandung: Rosda Karya, 2014), h.141.

136 Mohamad Surya, Psikologi Pembelajaran dan Pengajaran, (Bandung: Pustaka Bani Quraisy, 2004), h. 75.

${ }^{137}$ Oemar Hamalik, Psikologi Belajar Dan Mengajar, (Bandung: Sinar Baru Algensindo, 2009), h.78; Saifudin Azwar, Tes Prestasi (Fungsi dan Pengembangan Pengukuran Prestasi Belajar, (Yogyakarta: Pustaka Pelajar, 2012), h. 8-9.
} 
dua yaitu faktor interen dan faktor eksteren. Secara rinci faktor tersebut adalah sebagai berikut: 1). Faktor interen meliputi: a). Faktor jasmani yang terdiri atas faktor kesehatan dan cacat tubuh dan b). Faktor psikologi yang terdiri atas intelegensi, perhatian, minat, bakat, motif, kematangan, dan kelemahan. 2). Faktor eksteren meliputi : a). Faktor keluarga terdiri atas cara orang tua mendidik, relasi antar anggota keluarga, suasana rumah tangga dan keadaan ekonomi keluarga; b). Faktor sekolah terdiri atas metode mengajar, kurikulum, relasi guru dengan siswa, disiplin, keadaan gedung, metode mengajar, dan tugas belajar; c). Faktor masyarakat terdiri atas kegiatan siswa dalam masyarakat, media masa, teman bergaul, bentuk kehidupan masyarakat. ${ }^{138}$

\section{Indikator Prestasi Belajar.}

Indikator prestasi belajar adalah pengungkapan hasil belajar yang meliputi segenap ranah psikologis yang berubah sebagai akibat pengalaman dan proses belajar siswa. Ranah yang dimaksud antara lain ranah cipta, rasa dan karsa. ${ }^{139}$ Benjamin S. Bloom berpendapat bahwa taksonomi pendidikan harus mengacu kepada tiga jenis domain (daerah binaan atau ranah) yang melekat pada diri peserta didik, yaitu; 1). Ranah proses berpikir (cognitive domain); 2). Ranah nilai atau sikap (affective domain); dan 3). Ranah keterampilan (psycomotor domain). ${ }^{140}$

a. Ranah kognitif adalah ranah yang mencakup kegiatan mental (otak). Menurut Bloom, ranah ini menyangkut aktivitas otak. Dalam ranah kognitif terdapat enam jenjang proses berpikir dari jenjang terendah sampai dengan jenjang yang paling tinggi. Keenam jenjang tersebut adalah 1). Pengetahuan/hafalan/ingatan (knowledge); 2). Pemahaman (comprehension); 3). Penerapan (aplication); 4). Analisis (analysis); 5). Sintesis (synthesis); dan 6). Penilaian (evaluation).

1) Pengetahuan (knowledge) adalah kemampuan seseorang untuk mengingat-ingat kembali tentang nama, istilah, ide, gejala, rumus, dan sebagainya.

2) Pemahaman (comprehension) adalah kemampuan seseorang untuk mengerti atau memahami sesuatu setelah sesuatu itu diketahui dan diingat.

3) Penerapan atau aplikasi (aplication) adalah kesanggupan seseorang untuk menerapkan atau menggunakan ide-ide umum, tata cara atau metode-metode, prinsip-prinsip, rumus-rumus, teori-teori, dan sebagainya dalam situasi yang kongkrit.

4) Analisis (analysis) adalah kemampuan seseorang untuk merinci atau menguraikan suatu bahan atau keadaan menurut bagian-bagian yang

${ }^{138}$ Slameto, Belajar dan Faktor-faktor yang Mempengaruhinya, (Jakarta: Rineka Cipta, 2010), h.56.

${ }^{139}$ Muhibbin Syah, Psikologi Pendidikan, h.141.

${ }^{140}$ Anas Sudijono, Pengantar Evaluasi Pendidikan, (Jakarta: PT. RajaGafindo Persada, 2013), h. 48-59. 
lebih kecil dan mampu memahami hubungan diantara bagian-bagian atau faktor-faktor yang satu dengan yang lainnya.

5) Sintesis (synthesis) adalah kemampuan berpikir yang merupakan kebalikan dari proses berpikir analisis.

6) Penilaian/penghargaan/evaluasi (evaluation) merupakan jenjang berpikir paling tinggi dalam ranah kognitif.

b. Ranah afektif (Krathwohl: 1974) adalah ranah yang mencakup lima jenjang, yaitu; 1). Receiving; 2). Responding; 3). Valuing; 4). Organization;

5). Characterization by a value or value complex.

1) Receiving atau attending (menerima atau memperhatikan) adalah kepekaan seseorang dalam menerima rangsangan dari luar yang datang kepada dirinya dalam bentuk masalah, situasi, gejala dan lain-lain.

2) Responding (menanggapi) adalah kemampuan yang dimiliki oleh seseorang untuk mengikutsertakan dirinya secara aktif dalam fenomena tertentu dan membuat reaksi terhadapnya dengan salah satu cara.

3) Valuing (menilai) adalah memberikan nilai atau penghargaan terhadap suatu kegiatan sehingga apabila kegiatan itu tidak dikerjakan, dirasakan akan membawa kerugian dan penyesalan.

4) Organizatation (mengatur) adalah mempertemukan perbedaan nilai sehingga terbentuk nilai baru yang lebih universal, yang membawa kepada perbaikan umum.

5) Characterization by a value or value complex (karakterisasi dengan suatu nilai atau komplek nilai) adalah keterpaduan semua sistem nilai yang telah dimiliki seseorang yang mempengaruhi kepribadian dan tingkah lakunya.

c. Ranah Psikomotor adalah ranah yang berkaitan dengan keterampilan atau kemampuan bertindak setelah seseorang menerima pengalaman belajar tertentu. Menurut Simpson (1956), hasil belajar psikomotor ini tampak dalam bentuk keterampilan dan kemampuan bertindak individu.

Menurut Muhibbin Syah, pengungkapan hasil belajar meliputi segala ranah psikologis yang berubah sebagai akibat pengalaman dan proses belajar siswa. Namun demikian pengungkapan perubahan tingkah laku seluruh ranah, khususnya ranah afektif sangat sulit. Hal ini disebabkan perubahan hasil belajar itu ada yang bersifat intangible (tidak dapat diraba). Kunci pokok untuk memperoleh ukuran dan data hasil belajar siswa adalah garis-garis besar indikator dikaitkan dengan jenis prestasi yang hendak diungkapkan atau diukur.

\section{Hasil Belajar}

Evaluasi hasil belajar dilakukan untuk membuat keputusan mengenai hasil belajar siswa. Evaluasi dilakukan setelah terlebih dahulu sebelumnya dilakukan pengukuran atau testing hasil belajar. Pengukuran menggunakan testing hasil belajar merupakan cara pengumpulan data hasil belajar. 
Pengumpulan data akan menghasilkan skor-skor. Skor-skor hasil belajar itulah yang merupakan data hasil belajar. ${ }^{141}$

Skor-skor itu digolongkan menggunakan dua macam cara, yaitu berdasarkan unsur dan jumlah unsur. Menurut Crocker dan Algina membagi skor berdasarkan unsur menjadi tiga yaitu skor murni (true score), skor amatan (observe score) dan skor kesalahan (error score). ${ }^{142}$

Sedangkan skor berdasarkan jumlah unsurnya, skor dapat dibagi menjadi dua yaitu skor tunggal dan gabungan. ${ }^{143}$ Skor tunggal adalah skor yang hanya terdiri dari satu unsur. Skor ini diperoleh dari satu jenis tes hasil belajar dan diskor dengan satu aturan skor. ${ }^{144}$ Skor gabungan adalah skor yang mengandung lebih dari satu unsur sehingga skor merupakan gabungan beberapa unsur. ${ }^{145}$ Jadi, hasil belajar adalah hasil yang diperoleh dalam suatu kegiatan penilaian yang dilakukan setelah melakukan proses kegiatan belajar dengan tujuan mengukur tingkat keberhasilan belajar siswa dalam waktu tertentu.

\section{F. Pengaruh Pembelajaran Kitab Ta'lim al-Muta'allim terhadap Pembentukan Karakter.}

Pembelajaran kitab Ta'lim al-Muta'allim memiliki pengaruh positif dan signifikan terhadap pembentukan karakter. Hal ini terlihat dari nilai estimasi diperoleh nilai koefisien regresi pembelajaran kitab Ta'lim al-Muta'allim sebesar 0,358. Nilai ini berarti jika intensitas pembelajaran kitab Ta'lim al-Muta'allim ditingkatkan atau diturunkan sebesar satu satuan, maka nilai keputusan pembentukan karakter akan meningkat atau menurun sebesar 0,358 satuan. Dengan asumsi bahwa variabel independen konstan dan nilai $t_{\text {hitung }}=5,100$ dengan tingkat signifikansi 0,000 . Maka ini berarti nilai $t_{\text {hitung }}$ lebih besar dari $t_{\text {tabel }}$ sebesar 2,012 dengan tingkat taraf probability sebesar 5\%. Artinya, bahwa pembelajaran kitab Ta'lim al-Muta'allim dapat meningkatkan pembentukan karakter. Semakin baik pembelajaran kitab Ta'lim al-Muta'allim maka pembentukan karakter akan semakin meningkat lebih baik dan sebaliknya.

Pengaruh pembelajaran kitab Ta'lim al-Muta'allim terhadap pembentukan karakter santri pesantren Hubulo adalah sebesar 0,358 dengan taraf signifikan 0,000. Ini menunjukkan bahwa pengaruh pembelajaran kitab Ta'lim alMuta'allim terhadap pembentukan karakter santri pesantren Hubulo adalah lemah. Lemahnya pengaruh pembelajaran kitab Ta'lim al-Muta'allim terhadap pembentukan karakter santri disebabkan karena pembelajaran kitab Ta'lim alMuta'allim masih bersifat inisiatif dan tambahan, sehingga hasil yang diharapkan tidak bisa maksimal. Hasil yang tidak maksimal tersebut terjadi karena asumsi yang terbangun pada diri santri adalah setiap pelajaran yang bersifat tambahan biasanya tidak penting, sehingga kesungguhan santri dalam mengikuti

141 Ibid. h. 184-194.

${ }^{142}$ Linda Crocker dan James Algina, Introduction to Classical and Modern Test Theory, (For Worth: Holt, Rinehart and Winston. Inc, 1986), h. 107.

${ }^{143}$ Purwanto, Evaluasi Hasil Belajar, (Yogyakarta: Pustaka Pelajar, 2013), h. 192.

144 Ibid.

${ }^{145}$ Ibid. 
pelajaran tersebut lemah, karena tidak ada tuntutan untuk mempelajari dan menguasai pelajaran tersebut.

Besarnya hubungan antara Pembelajaran Kitab Ta'lim al-Muta'allim terhadap Pembentukan Karakter yang dihitung dengan koefisien korelasi adalah 0,601. Angka 0,601 koefisien korelasinya di atas 0,50, maka ini menunjukkan adanya hubungan yang kuat antara pembelajaran kitab Ta'lim al-Muta'allim dengan pembentukan karakter santri pesantren Hubulo. Angka positif pada besaran koefisien korelasi ini menunjukkan bahwa pembelajaran kitab Ta'lim alMuta'allim dengan pembentukan karakter santri memiliki hubungan yang erat dan positif, artinya semakin tinggi pembelajaran kitab Ta'lim al-Muta'allim, maka akan semakin tinggi juga pembentukan karakternya. Kuatnya hubungan ini ditunjukkan oleh besarnya korelasi sebesar 0,601 dengan tingkat signifikansi 0,000 . Secara umum kitab Ta'lim al-Muta'allim sudah populer dijadikan pelajaran wajib dalam membentuk karakter santri di pesantren. Hal ini wajar apabila kitab Ta'lim al-Muta'allim memiliki hubungan yang kuat dengan pembentukan karakter.

Besarnya nilai korelasi (R), yaitu sebesar 0,601 dan dijelaskan besarnya prosentase pengaruh variabel bebas terhadap variabel terikat yang disebut koefesien determinasi yang merupakan hasil dari penguadratan R. Output tersebut diperoleh koefesien determinasi (R2) sebesar 0,361. Artinya, pembelajaran kitab Ta'lim al-Muta'allim berpengaruh terhadap pembentukan karakter adalah sebesar 36,1\%, sedangkan $63,9 \%$ sisanya dipengaruhi oleh faktor lain. Kitab Ta'lim al-Muta'allim merupakan pelengkap dari proses pembentukan karakter santri sebelumnya. Faktor-faktor lain yang mempengaruhi langsung pada pembentukan santri pesantren Hubulo adalah pendidikan asrama, sekolah dan penerapan peraturan pesantren yang tercantum dalam buku peraturan hidup harian santri.

Pembelajaran kitab Ta'lim al-Muta'allim memberikan pengaruh positif dan signifikan terhadap pembentukan karakter santri pesantren Hubulo. Secara teoritis pengaruh pembelajaran kitab Ta'lim al-Muta'allim terhadap pembentukan karakter ini dapat dijelaskan dengan menggunakan teori Thomas Lickona (1991), bahwa pendidikan karakter adalah pendidikan untuk membentuk kepribadian seseorang melalui pendidikan budi pekerti, yang hasilnya terlihat dalam tindakan nyata seseorang, yaitu tingkah laku yang baik, jujur, bertanggung jawab, menghormati orang lain, kerja keras, dan sebagainya. ${ }^{146}$

\section{G. Pengaruh Pembelajaran Kitab Ta'lim al-Muta'allim terhadap Prestasi Belajar. \\ Hasil penelitian ini membuktikan bahwa pembelajaran kitab Ta'lim al-} Muta'allim berpengaruh positif dan signifikan terhadap prestasi belajar. Hal ini terlihat dari nilai estimasi diperoleh nilai koefisien regresi pembelajaran kitab Ta'lim al-Muta'allim sebesar 0,390. Nilai ini berarti jika intensitas pembelajaran kitab Ta'lim al-Muta'allim ditingkatkan atau diturunkan sebesar satu satuan,

${ }^{146}$ Heri Gunawan, Pendidikan Karakter (Konsep dan Implikasinya), (Bandung: Alfabeta: 2014), h. 23. 
maka nilai prestasi belajar akan meningkat atau menurun sebesar 0,390 satuan. Dengan asumsi bahwa variabel independen lain konstan dan nilai $t_{\text {hitung }}=5,523$ dengan tingkat signifikan 0,000 . Maka ini berarti nilai $t_{\text {hitung }}$ lebih besar dari $t_{\text {tabel }}$ sebesar 2,012 dengan tingkat signifikan sebesar 5\%. Artinya, bahwa pembelajaran kitab Ta'lim al-Muta'allim dapat meningkatkan prestasi belajar. Karena, semakin baik pembelajaran kitab Ta'lim al-Muta'allim maka prestasi belajar santri akan semakin baik dan sebaliknya.

Pengaruh pembelajaran kitab Ta'lim al-Muta'allim terhadap prestasi belajar santri pesantren Hubulo adalah sebesar 0,390. Ini menunjukkan bahwa pengaruh pembelajaran kitab Ta'lim al-Muta'allim terhadap prestasi belajar santri pesantren Hubulo adalah lemah. Lemahnya pengaruh pembelajaran kitab Ta'lim al-Muta'allim terhadap prestasi belajar disebabkan kegiatan ini masih bersifat tambahan. Kegiatan yang bersifat tambahan cenderung dianggap tidak penting, sehingga kesungguhan untuk menguasai pelajaran tersebut juga lemah.

Dilihat dari besarnya pengaruh pembelajaran kitab Ta'lim alMuta'allim terhadap prestasi belajar sebesar 0,390 dengan tingkat signifikan 0,000 menunjukkan bahwa pembelajaran kitab Ta'lim al-Muta'allim memiliki pengaruh di dalam meningkatkan prestasi belajar santri pesantren Hubulo. Apabila diteliti lebih dalam, angka 0,390 menunjukkan pengaruh yang cukup wajar mengingat proses peningkatan prestasi belajar santri di pesantren Hubulo tidak hanya melalui pembelajaran kitab Ta'lim al-Muta'allim. Faktor-faktor tersebut adalah tingkat kesulitan mata pelajaran, metode yang gunakan oleh guru mata pelajaran, bahan ajar yang digunakan, media yang dipakai, waktu pembelajaran, kompetensi guru dan kemauan santri itu sendiri dalam mengikuti proses kegiatan belajar mengajar.

Besarnya hubungan Pembelajaran Kitab Ta'lim al-Muta'allim terhadap Prestasi Belajar dihitung dengan koefisien korelasi adalah 0,631. Angka koefisien korelasinya di atas 0,50 maka ini menunjukkan adanya hubungan yang kuat antara pembelajaran kitab Ta'lim al-Muta'allim dengan prestasi belajar santri pesantren Hubulo. Angka positif pada besaran koefisien korelasi ini menunjukkan bahwa pembelajaran kitab Ta'lim al-Muta'allim dengan prestasi belajar santri memiliki hubungan yang erat dan positif, artinya semakin tinggi pembelajaran kitab Ta'lim al-Muta'allim, maka akan semakin tinggi juga prestasi belajarnya. Kuatnya hubungan ini ditunjukkan oleh besarnya korelasi sebesar 0,631 dengan tingkat signifikansi 0,000 . Secara umum kitab Ta'lim al-Muta'allim sudah populer dijadikan pelajaran wajib dalam meningkatkan prestasi belajar santri di pesantren. Hal ini menunjukkan bahwa kitab Ta'lim al-Muta'allim memiliki hubungan yang kuat dengan prestasi belajar.

Besarnya nilai korelasi (R) adalah sebesar 0,631 dan dijelaskan besarnya prosentase pengaruh variabel bebas terhadap variabel terikat yang disebut koefesien determinasi yang merupakan hasil dari penguadratan R. dari output tersebut diperoleh koefesien determinasi (R2) sebesar 0,399. Pengertiannya adalah pembelajaran kitab Ta'lim al-Muta'allim berpengaruh terhadap prestasi belajar adalah sebesar 39,9\%, sedangkan $61,1 \%$ sisanya dipengaruhi oleh faktor lain. Posisi kitab Ta'lim al-Muta'allim adalah sebagai pelengkap dari proses peningkatan prestasi belajar santri sebelumnya. 
Pembelajaran kitab Ta'lim al-Muta'allim memberikan pengaruh positif dan signifikan terhadap prestasi belajar santri pesantren Hubulo. Secara teoritis pengaruh pembelajaran kitab Ta'lim al-Muta'allim terhadap prestasi belajar ini dapat dijelaskan dengan menggunakan teori Benjamin S. Bloom, bahwa taksonomi pendidikan harus mengacu kepada tiga jenis domain (daerah binaan atau ranah) yang melekat pada diri peserta didik, yaitu; 1). Ranah proses berpikir (cognitive domain); 2). Ranah nilai atau sikap (affective domain); dan 3). Ranah keterampilan (psycomotor domain). ${ }^{147}$

\section{Kesimpulan}

Berdasarkan pembahasan di atas, maka dapat disimpulkan hal-hal sebagai berikut:

1. Pembelajaran kitab Ta'Timu al-Muta'allim memiliki pengaruh positif dan signifikan terhadap pembentukan karakter sebesar 0,358 dengan nilai konstan sebesar 37,154 dengan tingkat signifikansi 0,000. Nilai ini berarti jika intensitas pembelajaran kitab Ta'limu al-Muta'allim (X) ditingkatkan atau diturunkan sebesar satu satuan, maka nilai keputusan pembentukan karakter akan meningkat atau menurun sebesar 0,358 satuan. Besarnya pengaruh langsung pembelajaran kitab Ta'Timu al-Muta'allim terhadap pembentukan karakter sebesar 36,1\%, sedangkan kuatnya hubungan pembelajaran kitab Ta'limu al-Muta'allim terhadap pembentukan karakter termasuk dalam kategori kuat ditunjukkan dengan korelasi sebesar 0,601.

2. Pembelajaran kitab Ta'timu al-Muta'allim memiliki pengaruh positif dan signifikan terhadap prestasi belajar sebesar 0,390 dengan nilai konstan sebesar 10,767 dengan tingkat signifikansi 0,000. Nilai ini berarti jika intensitas pembelajaran kitab Ta' 'imu al-Muta'allim (X) ditingkatkan atau diturunkan sebesar satu satuan, maka nilai keputusan prestasi belajar akan meningkat atau menurun sebesar 0,390 satuan. Besarnya pengaruh langsung pembelajaran kitab Ta'Timu al-Muta'allim terhadap pembentukan karakter sebesar 39,9\%, sedangkan kuatnya hubungan pembelajaran kitab Ta'Timu al-Muta'allim terhadap pembentukan karakter termasuk dalam kategori kuat ditunjukkan dengan korelasi sebesar 0,631.

${ }^{147}$ Anas Sudijono, Pengantar Evaluasi Pendidikan, (Jakarta: PT. RajaGafindo Persada, 2013), h. 48-59. 


\section{DAFTAR PUSTAKA}

Aljufri, Abdul Kadir, Terjemah Ta'lim Muta'allim, Surabaya: Mutiara Ilmu Surabaya, 1995.

As'ad, Aly, Terjemah Ta'lim al-Muta'allim , Kudus: Menara Kudus, 2007.

Azwar, Saifuddin, Metode Penelitian, Yogyakarta: Pustaka Pelajar, 2010.

--------------,Tes Prestasi (Fungsi dan Pengembangan Pengukuran Prestasi Belajar, Yogyakarta: Pustaka Pelajar, 2012.

Bell Gredlen, Marget E, Belajar dan Membelajarkan, Jakarta: Rajawali Pers, 1991.

bin Ismail, Ibrahim, Al-Syarh Ta'lim al-Muta'llim, Indonesia: Maktabah Daar Ihya' al-Kutub al-'Arabiyah.

------------------, Al-Syarh Ta'lim al-Muta'llim Thariqa at-Ta'allum, Semarang: Karya Toha Putra.

Crocker, Linda dan Algina, James, Introduction to Classical and Modern Test Theory, For Worth: Holt, Rinehart and Winston. Inc, 1986.

Dimyati, Mudjiono, Belajar dan Pembelajaran, Jakarta: Rineka Cipta, 2009

Djamarah, Syaiful Bahri, Dr., Zain, Aswan, Dr, Prestasi Belajar dan Kompetensi Guru, Surabaya: Usaha Nasional, 1994.

Djudi, Konsep Belajar Menurut Al-Zarnuji, Semarang: Pusat Penelitian Walisongo, 1997.

Emzir, Metode Penelitian Pendidikan Kuantitatif dan Kualitatif : Korelasional, Eksperimen, Ex Post Facto, Etnografi, Grounded Theory dan Action Research, (Jakarta: PT. Rajagrafindo Persada, 2014), hlm. 38 .

Ghazali, Imam, Ihya' Ulumudin, Terj. Moh. Zuhri, Semarang: CV. Asy-Syifa, 2009.

Gunawan, Heri, Pendidikan Karakter (Konsep dan Implementasi), Bandung: Alfabeta, 2014.

Hamalik, Oemar, Psikologi Belajar Dan Mengajar, Bandung: Sinar Baru Algensindo, 2009.

Kartini, Kartono, Tinjauan Holistik Mengenai Tujuan Pendidikan Nasional, Jakarta: Paradnya Paramita, 1997.

Kementerian Agama RI, Mushaf Al-Qur'an 20 Baris, Bandung: Mikraj Kazanah Ilmu, 2011.

Koesoema, A.Doni, Pendidikan Karakter; Strategi Mendidik Anak di Zaman Modern, Jakarta: PT. Grasindo, 2007.

Kurniawan, Syamsul, Pendidikan Karakter : Konsepsi \& Implementasinya Secara Terpadu Di Lingkungan Keluarga, Sekolah, Perguruan Tinggi, \& Masyarakat, Yogyakarta: Ar-Ruzz, 2013.

Lois, Ma'luf, Al-Munjid fi al-Lugoh wa al-'A'lam, Beirut: Dar al-Masyriq, 1975. 
Majid, Abdullah \& Andayani, Dian, Pendidikan Karakter Perspektif Islam, Bandung: PT. Rosda Karya, 2012.

--------------, Pendidikan Karakter Perspektif Islam, Bandung: PT. Remaja Rosdakarya, 2011.

Marimba, Ahmad D., Pengantar Filsafat Pendidikan Islam, Bandung: Remaja Rosdakarya, 1989

Masrial, Teras Kuliah Belajar Mengajar, Padang: Angkasa Raya, 1993.

Mubarak, Zain, Membumikan Pendidikan Nilai, Bandung: Alfabeta, 2009.

------------, Psikologi Pendidikan dengan Pendekatan Baru, Bandung: Rosda 2014.

Munir, Abdullah, Pendidikan Karakter, Yogyakarta: al-Ma'arif, 2010.

Nashiruddin, Hamam, Tafhimu al-Muta'allim Fi Tarjamati Ta'lim alMuta'allim Thariqah at-Ta'allum, Magelang: Menara Kudus, 1963.

Pasaribu, I. L. dan Simandjuntak B., Metode Belajar dan Kesulitan Belajar, Bandung: Tarsito, 1983.

Poerwadarminta, W.J.S., Kamus Umum Bahasa Indonesia, Jakarta: PN. Balai Pustaka, 1985.

Priyatno, Duwi, Paham Anailsa Statistik Data dengan SPSS, Yogyakarta: Media Kom, 2010.

Purwanto, Evaluasi Hasil Belajar, Yogyakarta: Pustaka Pelajar, 2013.

Pusat Departemen Pendidikan Nasional, 18 Nilai Dalam Pendidikan Karakter Bangsa" dalam http.//rumahinspirasi.com. diakses tanggal 10 Desember 2016.

Ridwan, Dasar-Dasar Statistik ,Bandung: Alfabeta, 2013.

Ridwan dan Sunarto, Pengantar Statistik Untuk Penelitian, Bandung: Alfabeta, 2013.

Salim, Moh. Haitami dan Kurniawan, Syamsul, Studi Ilmu Pendidikan Islam, Yogyakarta: Ar-Ruzz Media, 2012.

Sjarkawi, Pembentukan Kepribadian Anak; Peran Moral, Intelektual, Emosional, dan Sosial Sebagai Wujud Membangun Jatidiri, Jakarta: PT. Bumi Aksara, 2006.

Slameto, Belajar dan Faktor-faktor yang Mempengaruhinya, Jakarta: Rineka Cipta, 2010.

Sudarsono, Etika Islam Tentang Kenakalan Remaja, Jakarta: Bina Aksara, 1989.

Sudijono, Anas, Prof. Drs., Pengantar Evaluasi Pendidikan, Jakarta: PT. RajaGafindo Peersada, 2013), hlm. 48-59.

Sudjana, Nana, Penilaian Hasil Proses Belajar Mengajar, Bandung: PT. Remaja Rosdakarya, 1990.

Sudjana, Metode Statistika, Bandung: Tarsito, 1996.

Sugiyono, Metode Penelitian Kombinasi (Mix Methods), Bandung: Alfabeta, 2014. 
Suharsimi, Arikunto, Dasar-Dasar Evaluasi Pendidikan, Jakarta: Rhineka Cipta, 2013.

Surya Brata, Sumardi, Psikologi Pendidikan, Jakarta: Raja Grafindo Persada, 1998.

Surya, Mohamad, Psikologi Pembelajaran dan Pengajaran, Bandung: Pustaka Bani Quraisy, 2004.

Psikologi Pendidikan Dengan Pendekatan Baru, Bandung:

PT.Remaja Rosda karya, 2008.

------------, Psikologi Pendidikan, Bandung: PT. Remaja Rosda Karya, 1995.

Tafsir, Ahmad, Metodologi Pedidikan Agama Islam, Bandung: PT. Remaja Rosdakarya Offset, 2008.

Tirtonegoro, Sutratinah, Anak Super Normal dan Program Pendidikannya, Jakarta: Bina Aksara, 2001.

Uno, Hamzah B, Perencanaan Pembelajaran, Jakarta: Bumi Aksara, 2008.

Yahiji, Kasim, Cara Mudah Memahami Kitab Gundul, "Strategi Pembelajaran Kitab Kuning di Pondok Pesantren”, Gorontalo: Sultan Amai Press IAIN Sultan Amai Gorontalo, 2011.

Yusuf, A. Muri, Metode Penelitian Kuantitatif, Kualitatif dan Penelitian Gabungan, Jakarta: Prenadamedia, 2015.

Zamroni, Pengantar Pengembangan Teori Sosial, Yogyakarta: Tiara Wacana, 1992.

Zubaedi, Desain Pendidikan Karakter: Konsepsi dan Aplikasinya Dalam Lembaga Pendidikan, Jakarta: Kencana Prenada Media Group, 2011.

Zuriah, Nurul, Metodologi Penelitian Sosial dan Pendidikan, Jakarta: Bumi Aksara, 2007. 